\title{
Plants and chemical constituents with giardicidal activity
}

\author{
Flavia M.M. Amaral ${ }^{1 *}$, Maria Nilce S. Ribeiro ${ }^{1}$, José M. Barbosa-Filho², Aramys S. Reis ${ }^{3}$, \\ Flávia R.F. Nascimento ${ }^{3}$, Rui O. Macedo ${ }^{2}$ \\ 'Departamento de Farmácia, Universidade Federal do Maranhão, Campus do Bacanga, Av. dos Portugueses s/n, \\ Prédio da Farmácia, 65085-580, São Luís, Maranhão, Brazil, \\ ${ }^{2}$ Laboratório de Tecnologia Farmacêutica "Delby Fernandes de Medeiros", Universidade Federal da Paraíba, \\ Caixa Postal 5009, 58051-970, João Pessoa, Paraíba, Brazil, \\ ${ }^{3}$ Laboratório de Imunofisiologia, Universidade Federal do Maranhão, Campus do Bacanga, Av. dos Portugueses \\ s/n, Prédio do Integrado, 65085-580, São Luis, Maranhão, Brazil
}

\begin{abstract}
RESUMO: "Plantas e constituintes químicos com atividade giardicida". Infecção intestinal causada por Giardia lamblia representa grave problema de saúde pública, com elevadas taxas de prevalência em diversos países. O aumento de resistência do parasita e os efeitos colaterais dos fármacos de referência empregados no tratamento da giardíase, tornam necessário a busca de novos agentes terapêuticos. Produtos naturais, especialmente de origem vegetal, representam excelentes fontes de pesquisas. Este trabalho tem como objetivo revisar a literatura de extratos de plantas, frações e compostos químicos com estudos in vitro de avaliação da atividade giardicida. A revisão refere 153 (cento e cinqüenta e três) espécies vegetais de 69 (sessenta e nove) famílias que foram submetidas à avaliação da atividade giardicida. Descreve a distribuição geográfica das espécies vegetais, parte usada, preparação, cepa de Giardia lamblia testada e resultados por autores. Apresenta 101 (cento e um) compostos isolados de espécies vegetais classificados por classes químicas. Discute aspectos recentes da pesquisa de produtos naturais de origem vegetal empregados no tratamento da giardíase.
\end{abstract}

Unitermos: Giardia lamblia, atividade giardicida, produtos naturais, plantas medicinais, revisão.

\begin{abstract}
Intestinal infection caused by Giardia lamblia represents a serious public health problem, with increased rates of prevalence in numerous countries. Increased resistance of the parasite and the side-effects of the reference drugs employed in the treatment of giardiasis make necessary to seek new therapeutic agents. Natural products, especially of plant origin, represent excellent starting point for research. The objective of this study is to review the literature on plant extracts, fractions and chemical constituents whose giardicidal activity has been investigated in vitro. The review describes 153 (one hundred and fifty-three) plant species from 69 (sixty-nine) families that were evaluated for their giardicidal activity. The geographical distribution of the plant species, the part used, preparation, strain of Giardia lamblia tested and the results obtained by the authors are also given. One hundred and one compounds isolated from plant species, classified by chemical class, are presented. Recent aspects of research on natural products of plant origin employed in the treatment of giardiasis are also discussed.
\end{abstract}

Keywords: Giardia lamblia, giardicidal activity, natural products, medicinal plants, review.

\section{INTRODUCTION}

Giardiasis is an intestinal infection caused by the flagellate protozoan Giardia lamblia (syn: Giardia intestinalis, Giardia duodenalis) with a broad, worldwide distribution and high rates of prevalence (Thompson et al., 2000; Adam, 2001; Sogayar; Guimarães, 2003). According to the World Health Organization, the worldwide incidence is around 500,000 new cases per year (WHO, 1998). In developed countries, including the United States and Canada, Giardia lamblia is the intestinal parasite most commonly associated with outbreaks of diarrhoea (Ortega; Adam, 1997; Tessier; Davies,
1999). In developing countries the average prevalence is $20 \%$ among the general population (Ortega; Adam, 1997; Rocha, 2003). In Brazil, some epidemiological studies have registered levels of up to $63.3 \%$, thereby constituting a serious public health problem (Cury et al., 1994; Guimarães; Sogayar, 1995; Newman et al., 2001).

During its evolutionary cycle Giardia lamblia presents in both cyst and trophozoital forms. The parasite is transmitted by faecal-oral contamination, through the ingestion of mature cysts present in untreated or inadequately treated water and contaminated foods. Direct person-to-person transmission through contaminated hands is common, mainly in group situations and 
among family members. There have also been reports of transmission through anal sex. However, contamination of humans through contact with infected animals is controversial (Adam, 1991; Flanagan, 1992; Nuñez et al., 2003; Rocha, 2003; Sogayar; Guimarães, 2003).

Giardia lamblia infection mainly affects children aged between 0 and 5 years, without distinction of sex, while the number of cases registered is significantly increased among homosexual men and immunocompromised individuals (Adam, 1991; Lebwohl et al., 2003; Sawangjaroen et al., 2005). Among Brazilian patients with acquired immunodeficiency syndrome, Giardia lamblia is the most frequent parasite related to intestinal diseases (Cimerman et al., 1999).

The majority of the hosts of Giardia lamblia is asymptomatic and plays an important role in the epidemiological chain, since, despite the absence of symptoms, they eliminate cysts, contributing significantly to the transmission of the disease (Tessier; Davies, 1999; Rey, 2001).

The clinical manifestations of giardiasis are varied, with diarrhoea being the predominant symptom, occurring in $90 \%$ of symptomatic patients. Diarrhoea may be acute and self-limiting or chronic and debilitating, associated with abdominal pain, flatulence, dyspepsia, epigastric pain, nausea, vomiting, and steatorrhea, malabsorption of fats and fat soluble vitamins and weight loss. The malabsorption of fats, carbohydrates, iron and vitamins $\left(A\right.$ and $B_{12}$ ) retards physical and intellectual development, mainly among younger age groups (Farthing et al., 1986; Heresi et al., 2000; Gendrel et al., 2003; Lebwohl et al., 2003; Al-Mekhlafi et al., 2005).

The treatment of giardiasis consists of the use of one or more drugs, with metronidazole being the first choice. Other nitroimidazolic derivatives (secnidazole, tinidazole, and ornidazole), benzimidazoles (albendazole, mebendazole), furazolin, quinacrine and paromomycin have also been employed in therapeutic regimens. However, these drugs have adverse effects including gastrointestinal disturbances, nausea, headache, leucopoenia and an unpleasant taste in the mouth. Furthermore, they can lead to neurotoxic effects, ataxia, convulsions and vertigo, bringing about the interruption of treatment. In addition, mutagenic and carcinogenic effects have been described in laboratory animals (Morgan et al., 1993; Heresi et al., 2000; Harris et al., 2001; Campanati; Monteiro-Leal, 2002; Petri-Jr., 2003).

Bearing in mind the side effects of the reference drugs and the increased resistance of the parasite to conventional treatment, it has become necessary to seek new, safe and effective agents for the treatment of the infection (Harris et al., 2001; Sousa; Silva, 2001; Upcroft; Upcroft, 2001; Sangster et al., 2002).

Plants represent an important source of drugs, considering the wide diversity of molecules with medicinal potential, and can make an effective contribution to the search of new bioactive products, semi-synthetic medicines or lead compounds for the synthesis of medicines (Cowan, 1999; Yunes; Calixto, 2001; Pinto et al., 2002; Anthony et al., 2005; Gilani; Rahman, 2005). The exploitation of this potential source of medicine requires the bringing together of ethnobotanical, ethnopharmacological, chemical, biological, pharmacological and toxicological studies (Gilani; Rahman, 2005; Gurib-Fakim, 2006).

In the search for new active products of plant origin, literature reviews concerning plant extracts, semipurified fractions and chemically defined molecules with biological activity have furnished important additional details, making an effective contribution to the definition of inclusion and/or exclusion criteria in the selection of plant species for the development of validation studies (Almeida et al., 2001; Sharma; Sharma, 2001; Pereira et al., 2002; Moura et al., 2002; Morais et al., 2003; Silva et al., 2003; Rocha et al., 2005; Falcão et al., 2005; BarbosaFilho et al., 2005; 2006a,b; Funke; Melzig, 2006).

With the aim of contributing to the search for new alternatives for the control of Giardia lamblia infection, the present work reviews the literature of studies examining in vitro giardicidal activity carried out with extracts, fractions and chemical substances of plant origin.

\section{MATERIAL AND METHODS}

This review covered Biological Abstracts, Chemical Abstracts, Medline, Web of Science, Lilacs and the data base of the University of Illinois-Chicago NAPRALERT (acronym for NAtural PRoducts ALERT), updated to June 2006. The references obtained in the review were consulted and analysed in details.

The key words employed in the literature review were Giardia lamblia $\mathrm{x}$ antigiardial activity $\mathrm{x}$ giardicidal activity $\mathrm{x}$ anti-protozoan activity $\mathrm{x}$ medicinal plants $\mathrm{x}$ natural products $\mathrm{x}$ natural compounds $\mathrm{x}$ in vitro $\mathrm{x}$ plant extracts.

\section{RESULTS AND DISCUSSION}

Following the proposed methodology, the study resulted in the elaboration of tables of extracts, fractions and pure chemical compounds that have been evaluated for their in vitro giardicidal activity (Tables 1 and 2).

The efficacy of the biological activity of plant materials under analysis can be related to the location and time of collection, the part of the plant used, preparation of the plant material, strain of Giardia lamblia tested and the assay employed. Such factors justify the development of studies with the same plant species, but obtained from different localities and/or at different times of collection, to investigate the giardicidal activity with different strains of the parasite, methodology and/or by diverse authors.

Review of the literature showed that the in vitro giardicidal activity had been investigated in 153 plant 
species, distributed among 69 (sixty-nine) families, including a notable representation of Asteraceae, Fabaceae, Rutaceae and Verbenaceae with 25, 10, 7 and 6 species studied, respectively.

Based on the results of the in vitro biological assessment according to the concentration of the extracts and fractions tested, we established criteria for the classification of giardicidal activity as highly active $\left(\mathrm{IC}_{50} \leq 100 \mu \mathrm{g} / \mathrm{mL}\right)$, active $\left(100<\mathrm{IC}_{50} \leq 250 \mu \mathrm{g} / \mathrm{mL}\right)$, moderately active $\left(250<\mathrm{IC}_{50} \leq 500 \mu \mathrm{g} / \mathrm{mL}\right)$ and inactive $\left(\mathrm{IC}_{50} \geq 500 \mu \mathrm{g} / \mathrm{mL}\right)$. The studies which did not give the concentration of the extracts and/or fractions analysed for $\mathrm{IC}_{50}, \mathrm{IC}_{90}$, and $\mathrm{IC}_{100}$ values and/or MIC, giardicidal activity were classified according to the criteria of efficacy (active or inactive) defined by the authors. Table 2 presents the results for giardicidal activity based on the criteria of efficacy and/or $\mathrm{IC}_{50}$ values established by the authors cited.

\section{Giardicidal activity of plant extracts and fractions}

Ethnobotanical and ethnopharmacological studies have shown the wide use of plant species in the treatment of gastrointestinal disturbances, such as diarrhoea and dysentery (Ivancheva; Stantcheva, 2000; Singh et al., 2002; El-Hilaly et al., 2003; Alanís et al., 2005; Gilani et al., 2005; Velázquez et al., 2006), which are the frequent manifestations of infection with Giardia lamblia.

The popular use of plants in the treatment of intestinal parasitoses, especially giardiasis, together with the side effects of the reference drugs and the increase in the parasite resistance, has prompted the investigation of natural products, with a view to validate the giardicidal property attributed empirically, and raise the possibility of new alternative therapies.

One of the pioneering studies on plant species with giardicidal activity was carried out in Africa by Johns et al. (1995). The authors investigated the giardicidal activity of 36 (thirty-six) plant species employed in the treatment of gastrointestinal disturbances by the population of the Luo region, in East Africa. The results showed that 21 (twenty-one) methanolic extracts obtained from the species studied brought about death or growth inhibition in trophozoites of Giardia lamblia. Table 1 presents the results for giardicidal activity, classified as active or inactive according to the criteria adopted by the authors, considering that the concentration of extracts and fractions tested was not related to the $\mathrm{IC}_{50}, \mathrm{IC}_{90}, \mathrm{IC}_{100}$ and/or MIC values.

Studies carried out with plant species from Cuba by Ordõnez et al. (2001) and from the USA by McAllister et al. (2001) demonstrated significant activity of Artemisia absinthium $\left(\mathrm{IC}_{50}: 200 \mu \mathrm{g} / \mathrm{mL}\right.$ ) and Yucca schidigera $\left(\mathrm{IC}_{50}: 15-250 \mu \mathrm{g} / \mathrm{mL}\right)$, respectively.

Recently, Sawangjaroen et al. (2005) reported that in Thailand patients infected with HIV and Giardia lamblia are known to self-medicate with plant species to treat giardiasis. The authors found that among the 12 (twelve) species tested, only 6 (six) exhibited significant giardicidal activity, with the most notable result being the efficacy of the chloroform extract of Alpinia galanga $\left(\mathrm{IC}_{50}: 37.73 \mu \mathrm{g} / \mathrm{mL}\right)$.

Aside from the scarce investigation of the giardicidal activity of extracts and fractions carried out in Africa, Brazil, China, Cuba, India, USA, Malaysia, Venezuela and Thailand, the largest contribution to this area of study has come from Mexico, where numerous plant species are used in popular medicine for the treatment of gastrointestinal illnesses, which has in turn stimulated validation studies (Calzada et al., 1998b; 1999b; 2005; 2006; Ponce-Macotela et al., 2001; TapiaPérez et al., 2003; Peraza-Sánchez et al., 2005).

A biological investigation reported by PonceMacotela et al. (1994), involving 14 (fourteen) plants used in Mexico for the treatment of diarrhoea and/or parasitic infections, demonstrated a percent inhibition of the growth of axenic strains of Giardia lamblia in excess of $50 \%$ for the extracts of Castela tortuosa, Haematoxylon campechianum, Mangifera indica, Cupressus sempervirens, Punica granatum, Psidium guajava, Plantago major, Justicia spicigera and Lippia spp. The criteria for efficacy (active or inactive) defined by the authors are expressed in the results presented in Table 1.

A study involving Althernanthera repens, Boerhavia coccinea, Flavenia trinerva, Leucaena esculenta, Tradescantia zebrina, Tournefortia densiflora, Vitex mollis and Waltheria americana; plant species used in traditional medicine in Mexico for the treatment of gastrointestinal disturbances, demonstrated that all of these species, except Tradescantia zebrina, possessed giardicidal activity at concentrations less than or equal to $100 \mu \mathrm{g} / \mathrm{mL}$, with the greatest effect being found in assays with extracts of the Tournefortia densiflora seeds (TapiaPérez et al., 2003).

In an assessment of the giardicidal activity of extracts and fractions obtained from 6 (six) plant species used by the population of Southern Mexico, Calzada et al. (1998a) found a greater efficacy of Rubus coriifolius, Cuphea pinetorum and Helianthemum glomeratum, with $\mathrm{IC}_{50}$ values of less than $100 \mu \mathrm{g} / \mathrm{mL}$.

Calzada et al. (1998b) reported a study carried out with the methanolic extracts of 19 (nineteen) plant species of Mexican origin, distributed among 13 (thirteen) families, and described potent giardicidal activity in 6 (six) species (Acalypha phleoides, Cnidoscolus tehuacanensis, Geranium nievum, Hellianthella quinquenervis, Heliopsis longipes and Teloxys graveolens), with $\mathrm{IC}_{50}$ values less than or equal to $20.64 \mu \mathrm{g} / \mathrm{mL}$.

Plant species selected for an ethnobotanical project, carried out in conjunction with Maya communities of the Yucatan peninsula (Mexico), were extracted with polar and non-polar solvents and tested for 
giardicidal activity, with the results showing that all the species returned $\mathrm{IC}_{50}$ values of below $90 \mu \mathrm{g} / \mathrm{mL}$ (Ankli et al., 2002). In addition, the methanolic extracts obtained from all 10 (ten) plant species tested which are native to the Yucatan peninsula (Mexico) exhibited giardicidal activity, with $\mathrm{IC}_{50}$ values between 6.34 and $117.41 \mu \mathrm{g} / \mathrm{mL}$; the most active species was Tridax procumbens (PerazaSánchez et al., 2005).

A recent investigation involving methanolic extracts of 26 (twenty-six) Mexican plant species found that 20 (twenty) possessed intense giardicidal activity, with $\mathrm{IC}_{50}$ values below $100 \mu \mathrm{g} / \mathrm{mL}$, while Dorstenia contrajerva was the most activite with an $\mathrm{IC}_{50}$ of 23.3 $\mu \mathrm{g} / \mathrm{mL}$ (Calzada et al., 2006).

In Brazil, there have been very few studies so far aimed at validating extracts and fractions with giardicidal activity. In the process of preparing this review, only 2 (two) studies were identified, carried out in Rio de Janeiro, which validated the use of Hovenia dulcis $\left(\mathrm{IC}_{50}\right.$ value: 12 $\mu \mathrm{g} / \mathrm{mL}$ for the dichloromethane fraction) (Gadelha et al., 2005 ) and Mentha x piperita $\left(\mathrm{IC}_{50}\right.$ values: $0.8 ; 2.5$ and 9.0 $\mu \mathrm{g} / \mathrm{mL}$ for the methanolic, dichloromethane and hexanic extracts, respectively) (Vidal et al., 2007).

According to the data presented in Table 1, it can be concluded that 117 (one hundred and seventeen) plant species, belonging mainly to the Asteraceae, Fabaceae, Rutaceae and Verbenaceae families exhibit in vitro giardicidal activity, classified as strongly active and active.

There is a great diversity of flora in Brazil which is mainly concentrated in the pre-Amazon region. There is also a tradition of usage of plants for therapeutic ends in this country. The high rate of intestinal parasitoses, mainly due to Giardia lamblia found in the Brazilian population is a motivation for studies on the giardicidal activity of plant species which are popular and in widespread use in Brazil. Therefore, much emphasis should be given in this line of research, with a view to contributing to alternatives based on natural products to combat this disease.

\section{Giardicidal activity of chemically defined molecules}

The literature review identified 101 (one hundred and one) chemical substances isolated from diverse plant species submitted to biological study for the assessment of in vitro giardicidal activity. The active compounds isolated and identified belonged to the classes of flavonoids (40), especially flavanols and isoflavones, as well as triterpenes (28), with the quassinoids being the most representative, alkaloids (18), mainly indole alkaloids, sesquiterpenes (04), steroids (04), phenolic acids and esters (03), lignan (01) and amine (01). These are presented in Table 2 in alphabetical order of their chemical names, followed by the class, plant species of origin, strain tested, results and references.

The data presented in Table 2 show that diverse flavonoids isolated from different plant species exhibited giardicidal activity demonstrated in the in vitro assay of cytotoxicity against trophozoites of Giardia lamblia, with $\mathrm{IC}_{50}$ values varying between 0.03 and $178.7 \mu \mathrm{g} / \mathrm{mL}$. Formononetin, an isoflavone isolated from Dalbergia frutescens, exhibited intense activity with an $\mathrm{IC}_{50}$ below that of metronidazole ${ }^{\circledR}$, the reference drug for the giardiasis treatment and employed as a positive control in the assays (Khan et al., 2000). Eleven compounds, including flavonoids, steroids and triterpenes were isolated from the genus Geranium, represented by the species Geranium mexicanum and Geranium niveum (Calzada et al., 1999a; 2001b; 2005).

Bruceantin, (-)-epicatechin, $\beta$-sitosterol, $\beta$ sitosterol3-O- $\beta$-D-glucopyranoside, hyperin, kaempferol, narcissin, quercetin and rutin are examples of compounds isolated from distinct plant species whose activity has been examined in vitro against different strains of Giardia lamblia by various authors (Gillin et al., 1982; Wright et al., 1993a; Calzada et al., 1999a; 1999b; 2001a; 2003; 2005; Calzada 2005; Arrieta et al., 2001; Alanís et al., 2003).

The great variety of chemical classes under study is indicative of diverse mechanisms of action involved in the lysis and death of Giardia lamblia cells, reinforcing the necessity for the development of complementary studies for the evaluation of the selectivity of the cytotoxicity of the compounds.

\section{CONCLUSION}

This literature review shows that the majority of extracts and fractions obtained from plant species employed in popular medicine for the treatment of diarrhoea and dysentery exhibit in vitro giardicidal activity, and these are mainly from species belonging to the Asteraceae, Fabaceae, Rutaceae and Verbenaceae families. These studies need further confirmation. The active compounds encountered so far may lead to the discovery of new drugs to combat this disiase.

\section{ACKNOWLEDGEMENTS}

The authors are grateful to the University of Illinois, Chicago, USA for permission to consult NAPRALERT, to the Coordenação de Aperfeiçoamento de Pessoal de Nível Superior (CAPES) through the Programa de Qualificação Institucional (PQI) and to the Conselho Nacional de Pesquisa (CNPq) for financial support.

\section{REFERENCES}

Adam RD1991. The biology of Giardia spp. Microbiol Rev 55: 706-732.

Adam RD 2001. Biology of Giardia lamblia. Clin Microbiol Rev 14: 447-475.

Alanís AD, Calzada F, Cervantes JA, Torres J, Ceballos GM 
2005. Antibacterial properties of some plants used in Mexican traditional medicine for the treatment of gastrointestinal disorders. J Ethnopharmacol 100: 153-157.

Alanís AD, Calzada F, Cedillo-Rivera R, Meckes M 2003. Antiprotozoal activity of the constituents of Rubus coriifolius. Phytother Res 17: 681-682.

Al-Mekhlafi H, Azlin M, Nor-Aini U, Shaik A, Sa'iah A, Fatmah MS, Ismail MG, Firdaus A, Aisah MY, Rozlida AR, Norhayati M 2005. Giardiasis as a predictor of childhood malnutrition in Orang Asli children in Malaysia. T Roy Soc Trop Med H 99: 686-691.

Almeida RN, Navarro DS, Barbosa-Filho JM 2001. Plants with central analgesic activity. Phytomedicine 8: 310-322.

Ankli A, Heinrich M, Bork P, Wolfram L, Bauerfeind P, Brun R, Schmid C, Weiss C, Bruggisser R, Gertsch J, Wasescha M, Sticher O 2002. Yucatec Mayan medicinal plants:evaluation based on indigenous uses. $J$ Ethnopharmacol 79: 43-52.

Anthony JP, Fyfe L, Smith H 2005. Plant active components - a resource for antiparasitic agents? Trends Parasitol 21: 462-468.

Arrieta J, Reyes B, Calzada F, Cedillo-Rivera R, Navarrete A 2001. Amoebicidal and giardicidal compounds from the leaves of Zanthoxylum liebmannianum. Fitoterapia 72: 295-297.

Barbosa-Filho JM, Vasconcelos THC, Alencar AA, Batista LM, Oliveira RAG, Guedes DN, Falcão HS, Moura MD, Diniz MFFM, Modesto-Filho J 2005. Plants and their active constituents from South, Central, and North America with hypoglycemic activity. Rev Bras Farmacogn 15: 392-413.

Barbosa-Filho JM, Medeiros KCP, Diniz MFFM, Batista LM, Athayde-Filho PF, Silva SM, Cunha EVL, Almeida JRGS, Quintas-Júnior LJ 2006a. Natural products inhibitors of the enzyme acetylcholinesterase. Rev Bras Farmacogn 16: 258-285.

Barbosa-Filho JM, Martins VKM, Rabelo LA, Moura MD, Silva MS, Cunha EVL, Souza MFV, Almeida RN, Medeiros IA 2006b. Natural products inhibitors of the angiotensin converting enzyme (ACE). A review between 1980-2000. Rev Bras Farmacogn 16: 421446.

Calzada F, Alanis AD, Meckes M, Tapia-Contreras A, CedilloRivera R 1998a. In vitro susceptibility of Entamoeba histolytica and Giardia lamblia to some medicinal plants used by the people of southern Mexico. Phytother Res 12: 70-72.

Calzada F, Meckes M, Cedillo-Rivera R, Tapia-Contreras A, Mata R 1998b. Screening of Mexican medicinal plants for antiprotozoal activity. Pharm Biol 36:305-309.

Calzada F, Cerda-Garcia-Rojas CM, Meckes M, CedilloRivera R, Bye R, Mata R 1999a. Geranins A and B, new antiprotozoal A-type proanthocyanidins from Geranium niveum. J Nat Prod 62: 705-709.

Calzada F, Meckes M, Cedillo-Rivera R 1999b. Antiamoebic and antigiardial activity of plant flavonoids. Planta Med 65: 78-80.

Calzada F, Cedillo-Rivera R, Mata R 2001a. Antiprotozoal activity of the constituents of Conyza filaginoides. $J$ Nat Prod 64: 671-673.

Calzada F, Cedillo-Rivera R, Bye R, Mata R 2001b. Geranins $\mathrm{C}$ and $\mathrm{D}$, additional new antiprotozoal A-type proanthocyanidins from Geranium niveum. Planta Med 67: 677-680.

Calzada F, Velázquez C, Cedillo-Rivera R, Esquivel B 2003. Antiprotozoal activiy of the constituents of Teloxys graveolens. Phytother Res 17: 731-732.

Calzada F 2005. Additional antiprotozoal constituents from Cuphea pinetotum, a plant used in Mayan tradicional medicine to treat diarrhea. Phytother Res 19: 725727.

Calzada F, Cervantes-Martínez JA, Yépez-Mulia L 2005. In vitro antiprotozoal activity from the roots of Geranium mexicanum and its constituents on Entamoeba histolytica and Giardia lamblia. J Ethnopharmacol 98: 191-193.

Calzada F, Yépez-Mulia L, Aguilar A 2006. In vitro susceptibility of Entamoeba histolytica and Giardia lamblia to plants used in Mexican traditional medicine for the treatment of gastrointestinal disorders. $J$ Ethnopharmacol 108: 367-370.

Campanati L, Monteiro-Leal LH 2002. The effects of the antiprotozoal drugs metronidazole and furazolidone on trophozoites of Giardia lamblia (P1 strain). Parasitol Res 88: 80-85.

Cimerman S, Cimerman B, Lewi DS 1999. Prevalence of intestinal parasitic infections in patients with acquired immunodeficiency syndrome in Brazil. Int J Infect Dis 3: 203-206.

Cowan MM 1999. Plants products as antimicrobial agents. Clin Microbiol Rev 12: 564-582.

Cury GC, Salles PGO, Reis MCW, Rego VM, Arndt AW, Souza-Filho CBA, Moreira HB, Abreu MS, Leite PMG 1994. Prevalência da esquistossomose mansoni e de parasitoses intestinais em escolares da área rural do Município de Jaboticatubas, MG, 1992-1993. Rev Soc Bras Med Trop 27: 217-220.

Damak N, Ghorbel H, Bahroun A, Damak M, Mc Killop A, Simmonds M 2000. Contribution to structural investigation of Centaurea dimorpha compounds. $J$ Soc ChimTunis 4: 653-658.

Dou JH, McChesney JD, Sindelar RD, Goins DK, Khan IA, Walker LA 1996. A new quassinoid from crude quassin-extract of Quassia amara. Int J Pharmacogn 34: 349-354

El-Hilaly J, Hmammouchi M, Loyussi B 2003. Ethnobotanical studies and economic evaluation of medicinal plants in Taounate province (Northern Morocco). $J$ Ethnopharmacol 86: 149-158

El-Sohly HN, Joshi AS, Nimrod AC 1999. Antigiardial isoflavones from Machaerium aristulatum. Planta Med 65: 490 .

Falcão HS, Lima IO, Santos VL, Dantas HF, Diniz MFFM, Barbosa-Filho JM, Batista LM 2005. Review of the plants with anti-inflammatory activity studied in Brazil. Rev Bras Farmacogn 15: 381-391.

Farthing MJ, Mata L, Urrutia JJ, Kronmal RA 1986. Natural history of Giardia infection of infants and children in rural Guatemala and its impact on physical growth. Am J Clin Nutr 43:395-405.

Flanagan PA 1992. Giardia: diagnosis, clinical course and epidemiology. A review. Epidemiol Infec 109: 1-22.

Funke I, Melzig MF 2006. Traditionally used plants in diabetes therapy - phytotherapeutics as inhibitors of $\alpha$-amylase activity. Rev Bras Farmacogn 16: 1-5. 
Gadelha APR, Vidal F, Castro TM, Lopes CS, Albarello N, Coelho MGP, Figueiredo SFL, Monteiro-Leal LH 2005. Susceptibility of Giardia lamblia to Hovenia dulcis extracts. Parasitol Res 97: 399-407.

Gendrel D, Treluyer JM, Richard-Lenoble D 2003. Parasitic diarrhoea in normal and malnourished children. Fund Clin Pharmacol 17: 189-198.

Gilani AH, Rahman A 2005. Trends in ethnopharmacology. $J$ Ethnopharmacol 100: 43-49.

Gilani AH, Shah AJ, Ghayur MN, Majeed K 2005 Pharmacological basis for the use of turmeric in gastrointestinal and respiratory disorders. Life Sci 76: 3089-3105

Gillin FD, Reiner DS, Suffness M 1982. Bruceantin, a potent amoebicide from a plant, Brucea antidysenterica. Antimicrob Agents Ch 22: 342-345.

Guimarães S, Sogayar MIL 1995. Ocurrence of Giardia lamblia in children of municipal day-care centers from Botucatu, São Paulo State, Brazil. Rev Inst Med Trop São Paulo 37: 501-506.

Gurib-Fakim A 2006. Medicinal plants: traditions of yesterday and drugs of tomorrow. Mol Aspects Med 27: 1-93.

Harris JC, Plummer S, Lloyd D 2001. Antigiardial drugs. Appl Microbiol Biotechnol 57: 614-619.

Harris JC, Plummer S, Turner MP, Lloyd D 2000. The microaerophilic flagellate Giardia intestinalis: Allium sativum (garlic) is an effective antigiardial. Microbiology 146: 3119-3127.

Hegenscheid B, PresberW, Torres D, Mendiela J, Herrmann D 1992. Inhibition of growth of different protozoan species by an extract of Cochlospermum angolense (Welw). Med Microbiol Lett 1: 232-237.

Heresi GP, Murphy JR, Cleary TG 2000. Giardiasis. Semin Pediatr Infect Dis 11: 189-195.

Ivancheva S, Stantcheva B 2000. Ethnobotanical inventory of medicinal plants in Bulgaria. J Ethnopharmacol 69 : 165-172.

Johns T, Faubert GM, Kokwaro JO, Mahunnah RLA, Kimanani EK 1995. Anti-giardial activity of gastrointestinal remedies of the Luo of East Africa. J Ethnopharmacol 46: 17-23

Kaneda Y, Tanaka T, Saw T 1990. Effects of berberine, a plant alkaloid, on the growth of anaerobic protozoa in axenic culture. Tokai J Exp Clin Med 15: 417-423.

Khan IA, Avery MA, Burandt CL, Goins DK, Mikell JR, Nash TE, Azadegan A, Walker LA 2000. Antigiardial activity of isoflavones from Dalbergia frutescens bark. J Nat Prod 63: 1414-1416.

Lebwohl B, Deckelbaum RJ, Green PH R. 2003. Giardiasis. Gastrointest Endosc 57: 906-913.

McAllister TA, Annett CB, Cockwill CL, Olson ME, WangY, Cheeke PR 2001. Studies on the use of Yucca schidigera to control giardiasis. Vet Parasitol 97: 8599.

Meckes M, Calzada F, Tapia-Contreras A, Cedillo-Rivera R 1999. Antiprotozoal properties of Helianthemum glomeratum. Phytother Res 13: 102-105.

Moon T, Wilkinson JM, Cavanagh HMA 2006. Antiparasitic activity of two Lavandula essential oils against Giardia duodenalis, Trichomonas vaginalis and Hexamita inflata. Parasitol Res 99: 722-728.

Morais LCSL, Barbosa-Filho JM, Almeida RN 2003. Plants and bioactive compounds for the treatment of Parkinson's
Disease. Arquivos Brasileiros de Fitomedicina Cientifica 1: 127-132.

Morgan UM, Reynoldson JA, Thompson RCA 1993. Activities of several benzimidazoles and tubulin inhibitors against Giardia spp. in vitro. Antimicrob Agents Ch 37: 328-331.

Moura MD, Silva JS, Oliveira RAG, Diniz MFFM, BarbosaFilho JM 2002. Natural products reported as potential inhibitors of uterine cervical neoplasia. Acta Farma Bonaerense 21: 67-74.

Newman RD, Moore SR, Lima AAM, Nataro, J.P, Guerrant RL, Sears CL 2001. A longitudinal study of Giardia lamblia infection in north-east Brazilian children. Trop Med Int Health 6: 624-634.

Núñez FA, López JL, Cruz AM, Finlay CM 2003. Factores de riesgo de la infección por Giardia lamblia em niños de guarderías infatiles de Ciudad de La Habana, Cuba. Cadernos de Saúde Pública 19: 677-682.

Ordóñez MG, Idavov DT, Pol LM 2001. Validación del uso tradicional de plantas medicinales cultivadas en Cuba. Revista Cubana de Plantas Medicinales 2: 48-51.

Ortega YR, Adam RD 1997. Giardia: overview and update. Clin Infect Dis 25: 545-549.

Passreiter CM, Sandoval-Ramirez J, Wright CW 1999. Sesquiterpene lactones from Neurolaena oaxacana. $J$ Nat Prod 62: 1093-1095.

Peraza-Sánchez S, Poot-Kantún S, Torres-Tapia LW, May-Pat F, Simá-Polanco P, Cedillo-Rivera R 2005. Screening of native plants from Yucatan for anti-Giardia lamblia activity. Pharm Biol 43: 594-598.

Pereira JV, Modesto-Filho J, Agra MF, Barbosa-Filho JM 2002. Plant and plant-derived compounds employed in prevention of the osteoporosis. Acta Farma Bonaerense 21: 223-234.

Petri-Jr WA 2003. Therapy of intestinal protozoa. Trends Parasitol 19: 523-526.

Pinto AC, Silva DHS, Bolzani VS, Lopes NP, Epifanio RA 2002. Current status challenges and trends on natural products in Brazil. Quim Nova 25: 45-61.

Ponce-Macotela M, Navarro-Alegría I, Martínez-Gordillo MN, Alvarez C 1994. Efecto antigiardiásico in vitro de 14 extractos de plantas. Rev Invest Clin 46: 343-347.

Ponce-Macotela M, Rufino-González Y, Mora-de-la-Mora JI, González MA, Reynoso-Robles R, Martinez-Gordillo M 2001. Mortality and morphological changes in Giardia duodenalis induced by exposure to ethanolic extracts of Justicia spicigera. P West Pharmacol 44: 151-152.

Ponce-Macotela M, Rufino-Gonzáles Y, Gonzáles-Maciel A, Reynoso-Robles R, Martinez-Gordilho MN 2006. Orégano (Lippia spp.) kills Giardia duodenalis trophozoites in vitro: antigiardasic and ultrastructural damage. Parasitol Res 98: 557-569.

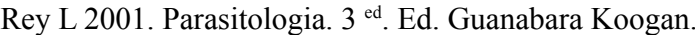

Rocha LG, Almeida JRGS, Macêdo RO, Barbosa-Filho JM 2005. A review of natural products with antileishmanial activity. Phytomedicine 12: 514-535.

Rocha MO 2003. Giardia duodenalis: axenização $e$ caracterização de três isolados do Brasil, empregando parâmetros biológicos, bioquímicos, imunológicos e moleculares. Belo Horizonte, 112p. Tese de Doutorado - Faculdade de Farmácia, Universidade Federal de Minas Gerais. 
Said-Fernández S, Guerra MCR, Cárdenas BDM, Villarreal JV, Treviño LV 2005. In vitro antiprotozoal activity of the leaves of Artemisia ludoviciana. Fitoterapia 76: 466468.

Said IM, Ahmad IB, Yahya MD, Marini AM 2001. Biological activity studies of Ancistrocladus tectorius. Pharm Biol 39: 357-363.

Sangster N, Batterham P, Chapman HD, Duraisingh M, Jabre LL, Shirley M, Upcroft J, Upcroft P 2002. Resistence to antiparasitic drugs: the role of molecular diagnosis. Int J Parasitol 32: 637-653.

Sawangjaroen N, Subhadhirasakul S, Phongpaichit S, Siripanth C, Jamjaroen K, Sawangjaroen K 2005. The in vitro anti-giardial activity of extracts from plants that are used for self-medication by AIDS patients in southern Thailand. Parasitol Res 95: 17-21.

Silva JS, Moura MD, Oliveira RAG, Diniz MFFM, BarbosaFilho JM 2003. Natural products inhibitors of ovarian neoplasia. Phytomedicine 10: 221-232.

Singh AK, Raghubanshi AS, Singh JS 2002. Medical ethnobotany of the tribals of Sonaghati of Sonbhadra district, Uttar Pradesh, India. J Ethnopharmacol 81: 31-41.

Sharma P, Sharma JD 2001. A review of plant species assessed in vitro for antiamoebic activity or both antimoebic and antiplasmodial properties. Phytother Res 15,:117.

Soffar SA, MokhtarGM 1991. Evaluation of the antiparasitic effect of aqueous garlic (Allium sativum) extract in hymenolepiasis nana and giardiasis. J Egypt Soc Parasitol 21: 497-502.

Sogayar MITL, Guimarães S 2003. Giardia lamblia. In: Neves DP, Melo AL, Genaro O, Linardi PM. Parasitologia humana. $10^{\text {ed }}$, Ed. Atheneu, $428 \mathrm{p}$.

Sousa MC, Silva JP 2001. The cytotoxic effects of ciprofloxacin in Giardia lamblia trophozoites. Toxicol In Vitro 15: 297-301.

Tapia-Pérez ME, Tapia-Contreras A, Cedillo-Rivera R, Osuna L, Meckes M 2003. Screening of Mexican medicinal plants from antiprotozoal activity-Part II, Pharm Biol 41: 180-183.

Tessier JL, Davies GAL1999. Giardiasis. Infect Dis Update 6: 8-11.

Thompson RCA, Hopkins RM, Homan WL 2000. Nomenclature and genetic groupings of Giardia infecting mammals. Parasitol Today 16: 210-213.

Tripathi DM, Gupta N, Lakshmi V, Saxena KC, Agrawal AK 1999. Antigiardial and immunostimulatory effect of Piper longum on giardiasis due to Giardia lamblia. Phytother Res 13: 561-565.

Upcroft J, Upcroft P 2001. Drug targets and mechanisms of resistance in the anaerobic protozoa. Clin Microbiol Rev 14: 150 -164.

Velázquez C, Calzada F, Torres J, González F, Ceballos G 2006. Antisecretory activity of plants used to treat gastrointestinal disorders in México. $J$ Ethnopharmacol 103: 66-70.

Vidal F, Vidal JC, Gadelha AP, Lopes CS, Coelho MG, Monteiro-Leal LH 2007. Giardia lamblia: The effects of extracts and fractions from Mentha x piperita Lin. (Lamiaceae) on trophozoites. Exp Parasitol 115: 2531.

World Health Organization (WHO) 1998. The World Health
Report. Life in the 21st Century: Vision for all.2. Measuring Health. World Health Organization, Geneva, Switzerland, 39-60.

Wright CW, Anderson MM, Allen D, Phillipson JD, Kirby GC, Warhurst DC, Chang HR 1993a. Quassinoids exhibit greater selectivity against Plasmodium falciparum than against Entamoeba histolytica, Giardia intestinalis or Toxoplasma gondii in vitro. J Eukaryot Microbiol 40: 244-246.

Wright CW, Allen D, Phillipson JD, Kirby GC, Warhurst DC, Massiot G, Le Men-Oliver L 1993b. Alstonia species: are they effective in malaria treatment? $J$ Ethnopharmacol 40: 41-45.

Wright CW, Allen D, Cai Y, Chen ZP, Phillipson JD, Kirby GC, Warhurst DC, Tits M, Angenot L 1994. Selective antiprotozoal activity of some Strychnos alkaloids. Parasitol Res 8: 149-152.

Yu HW, Wright CW, Cai Y, Yang SL, Phillipson JD, Kirby GC, Warshurst DC 1994. Antiprotozoal activites of Centipeda minima. Parasitol Res 8: 436-438.

Yunes RA, Calixto JB. 2001. Plantas medicinais sob a ótica da química medicinal moderna. Chapecó: Argos, 500p. 


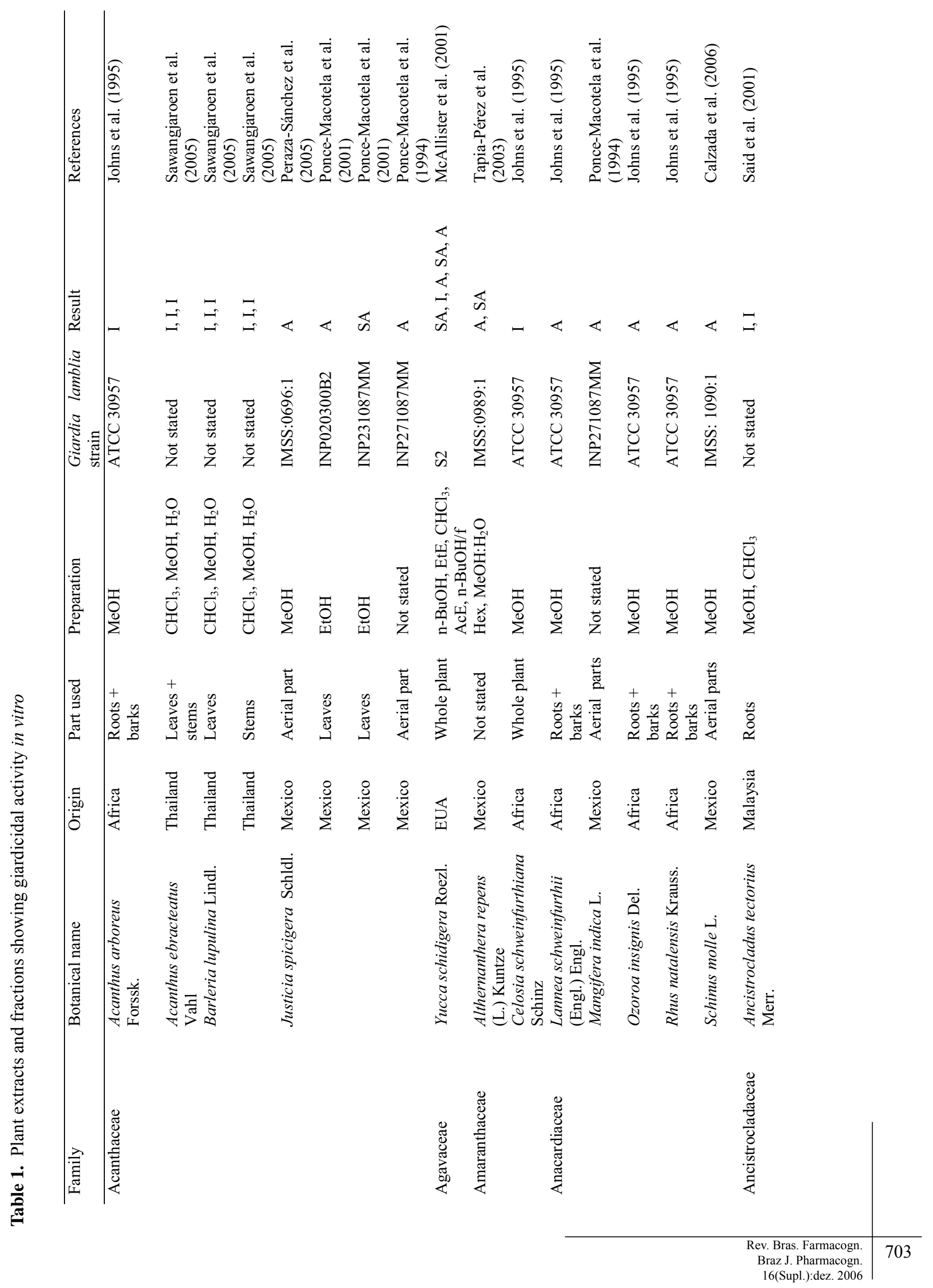




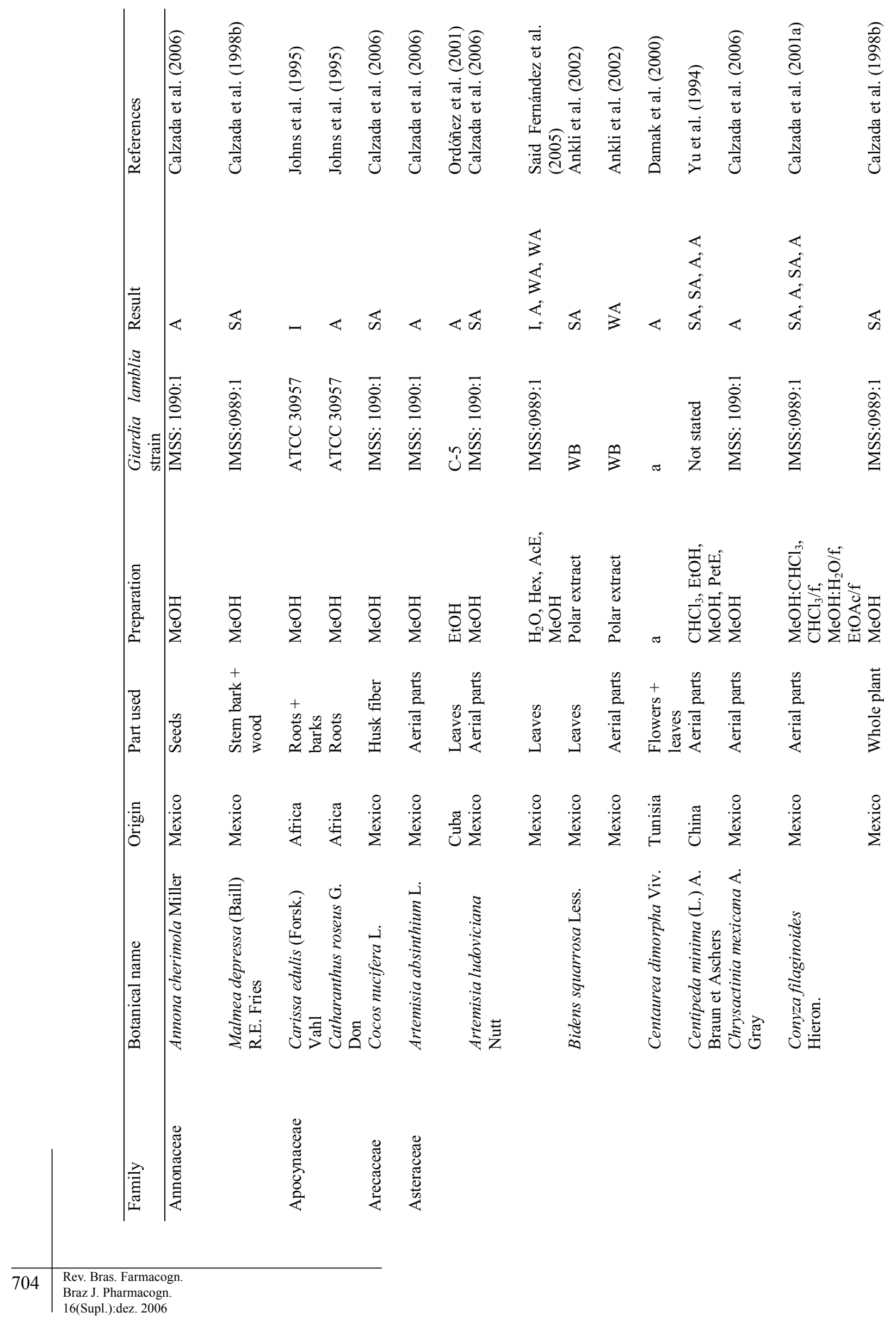




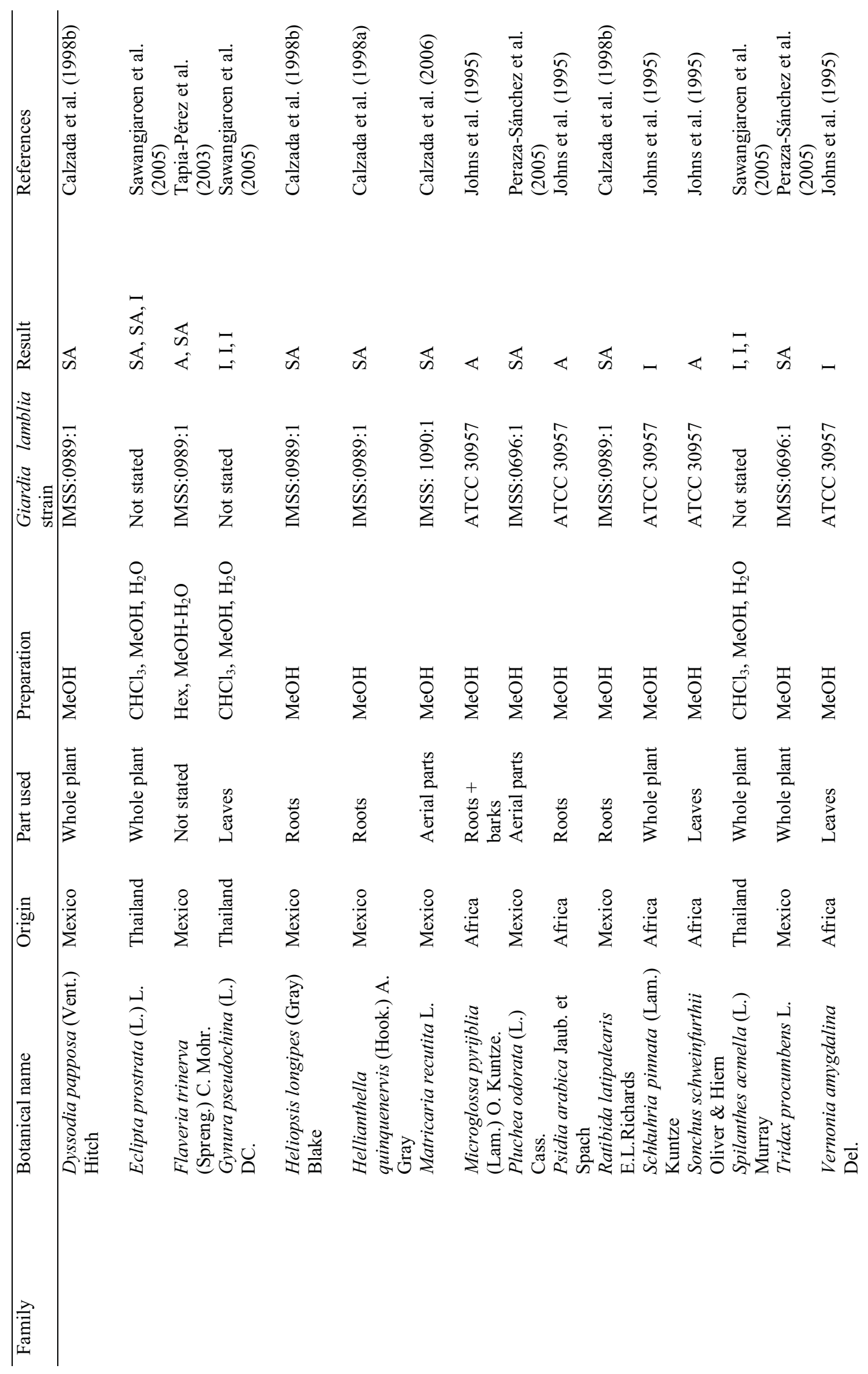




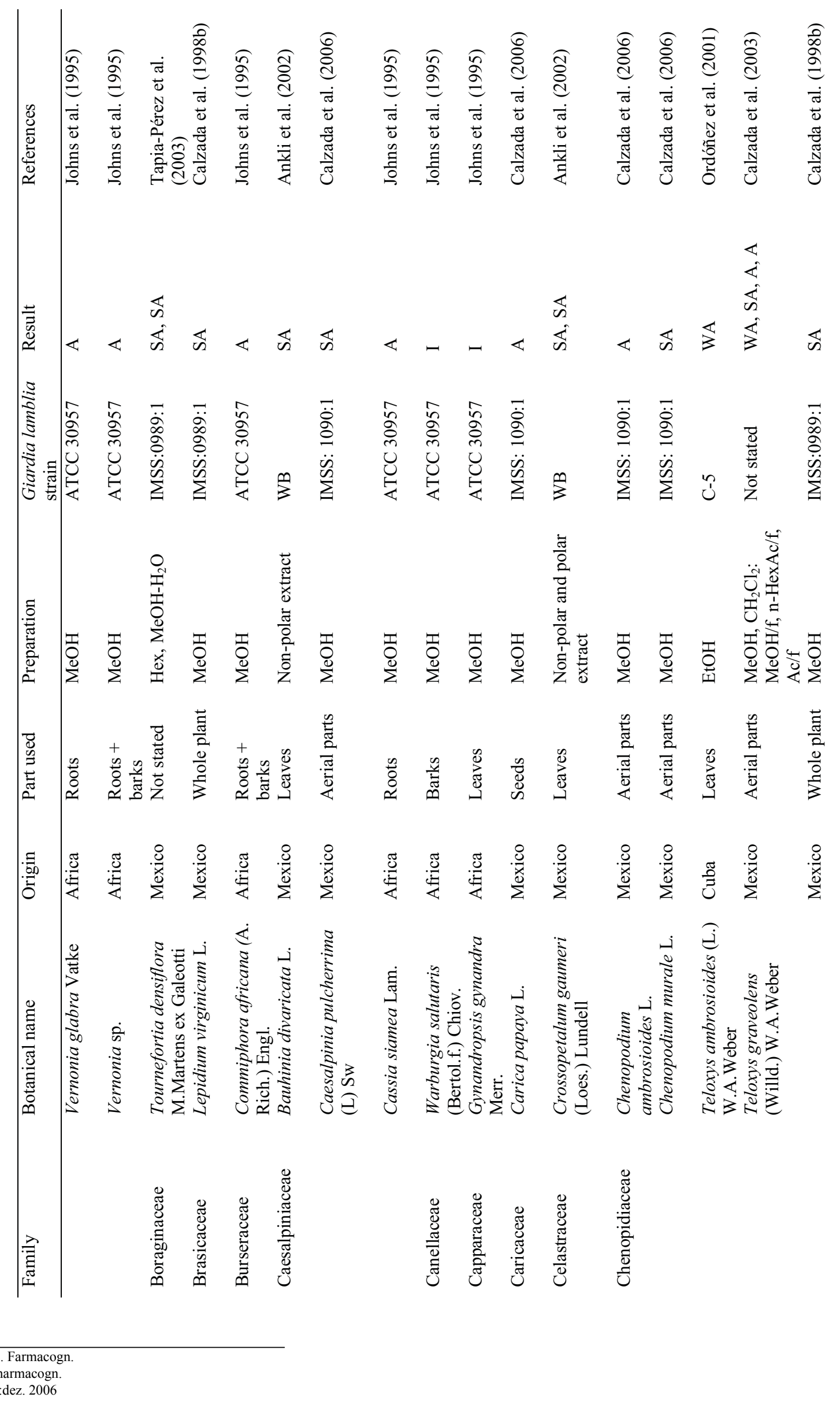




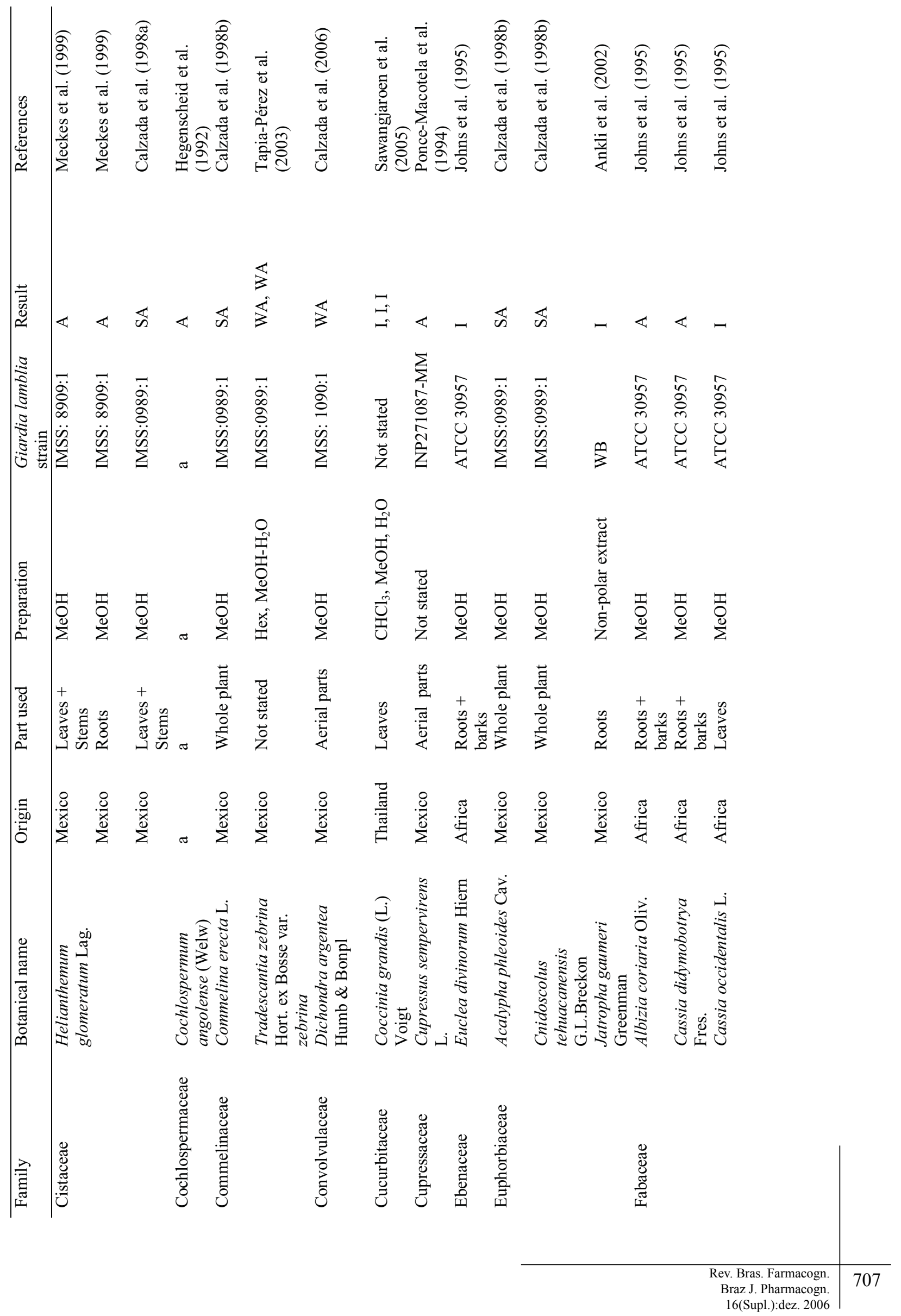




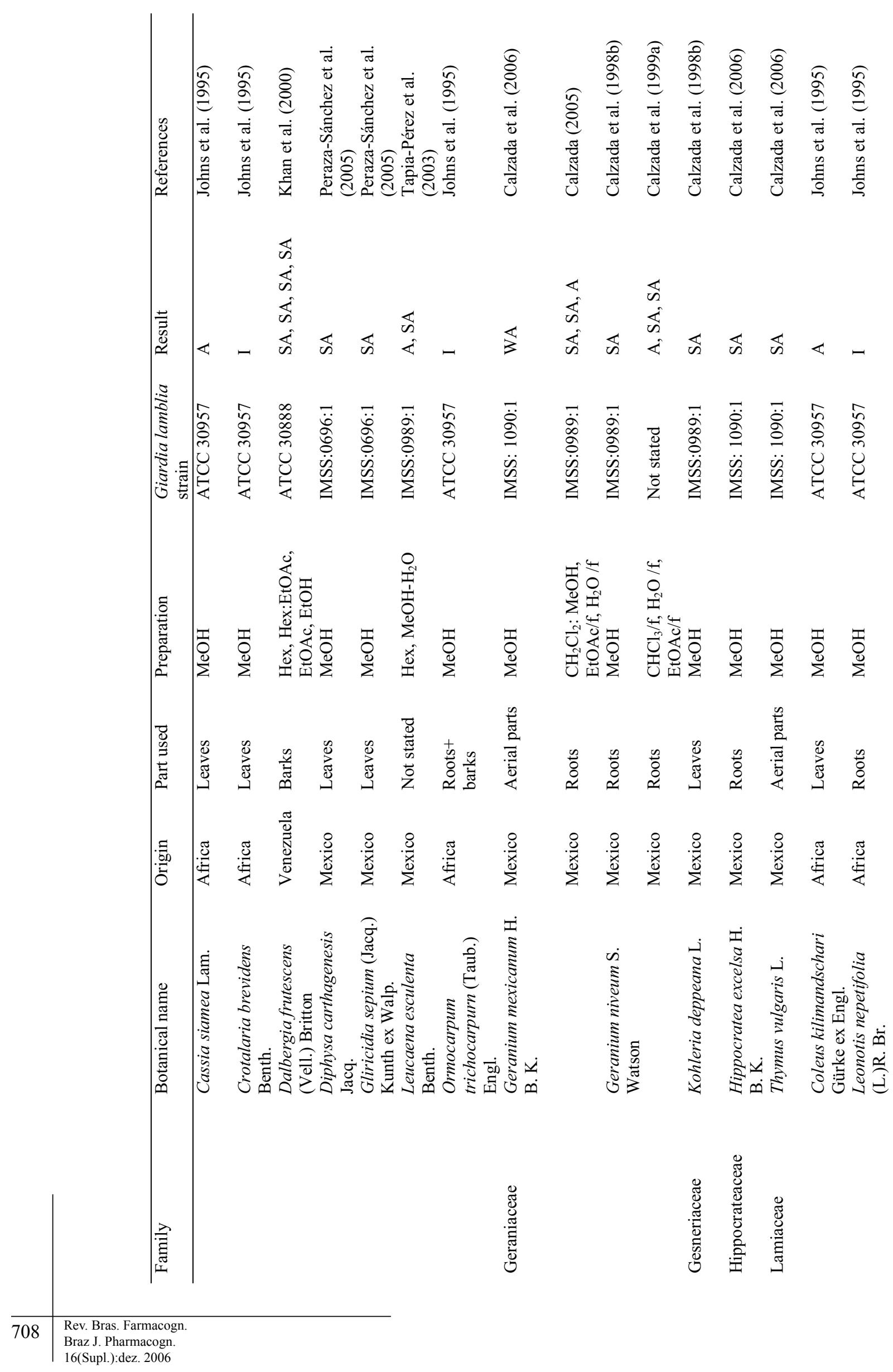




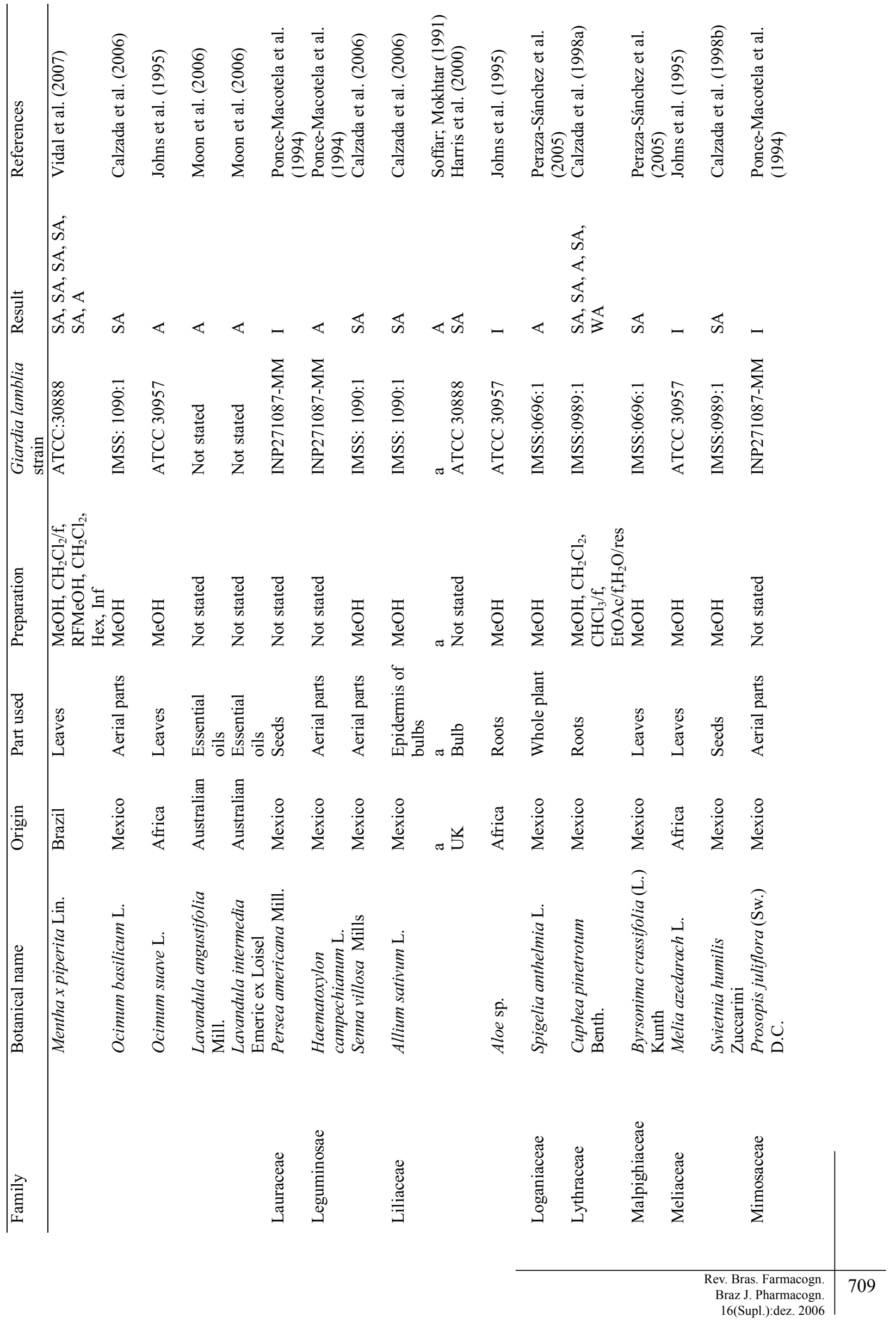




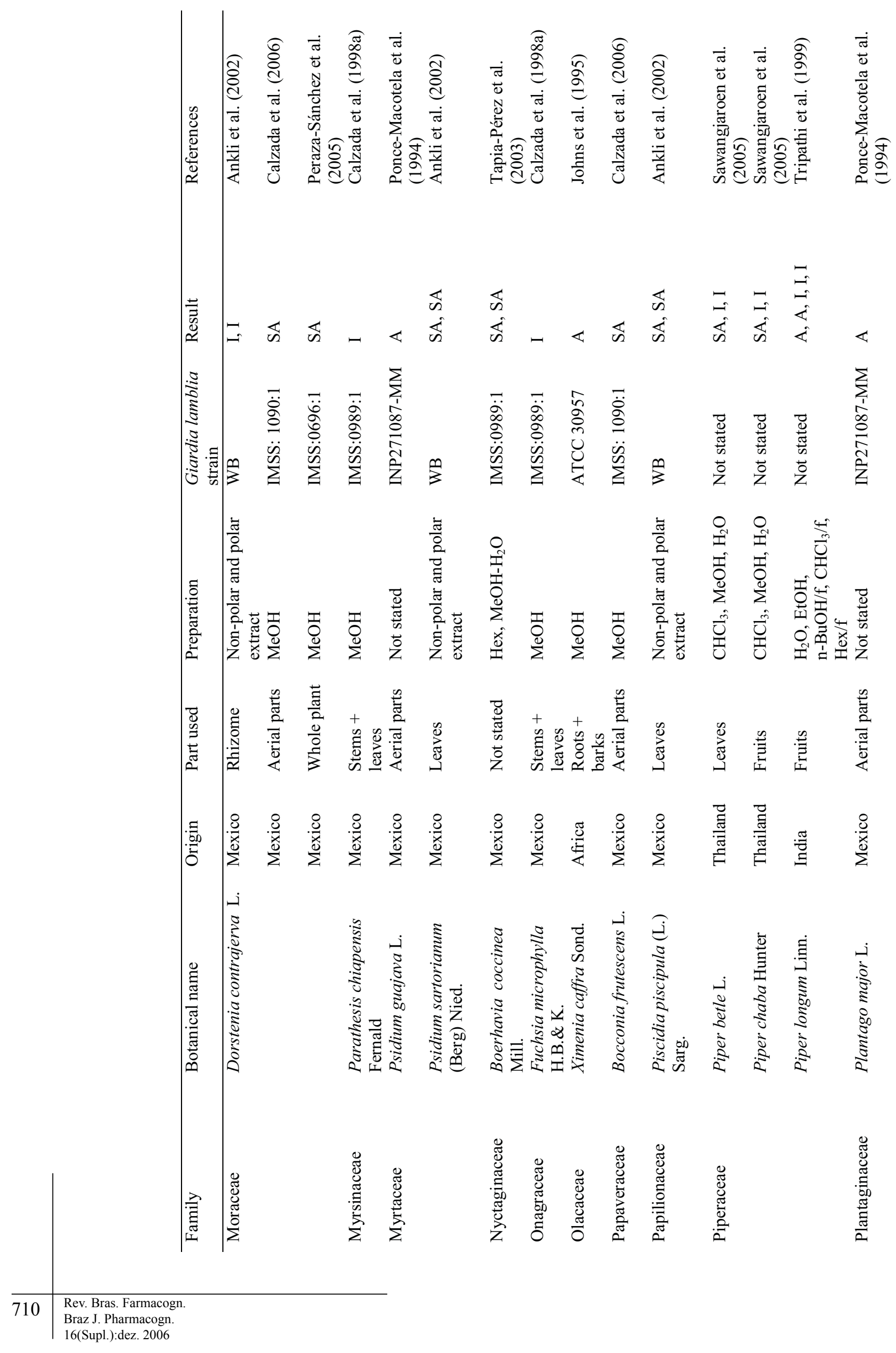




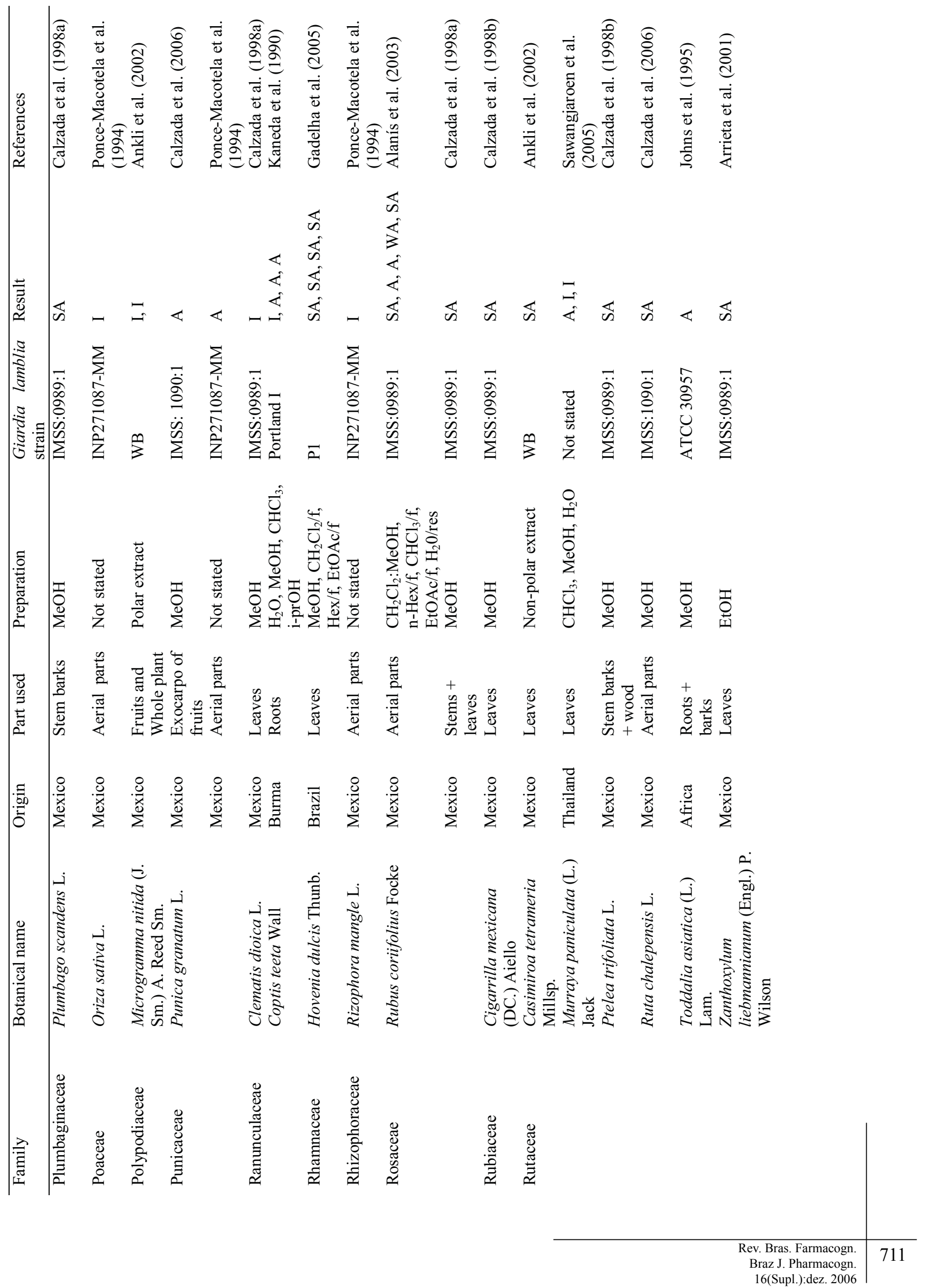




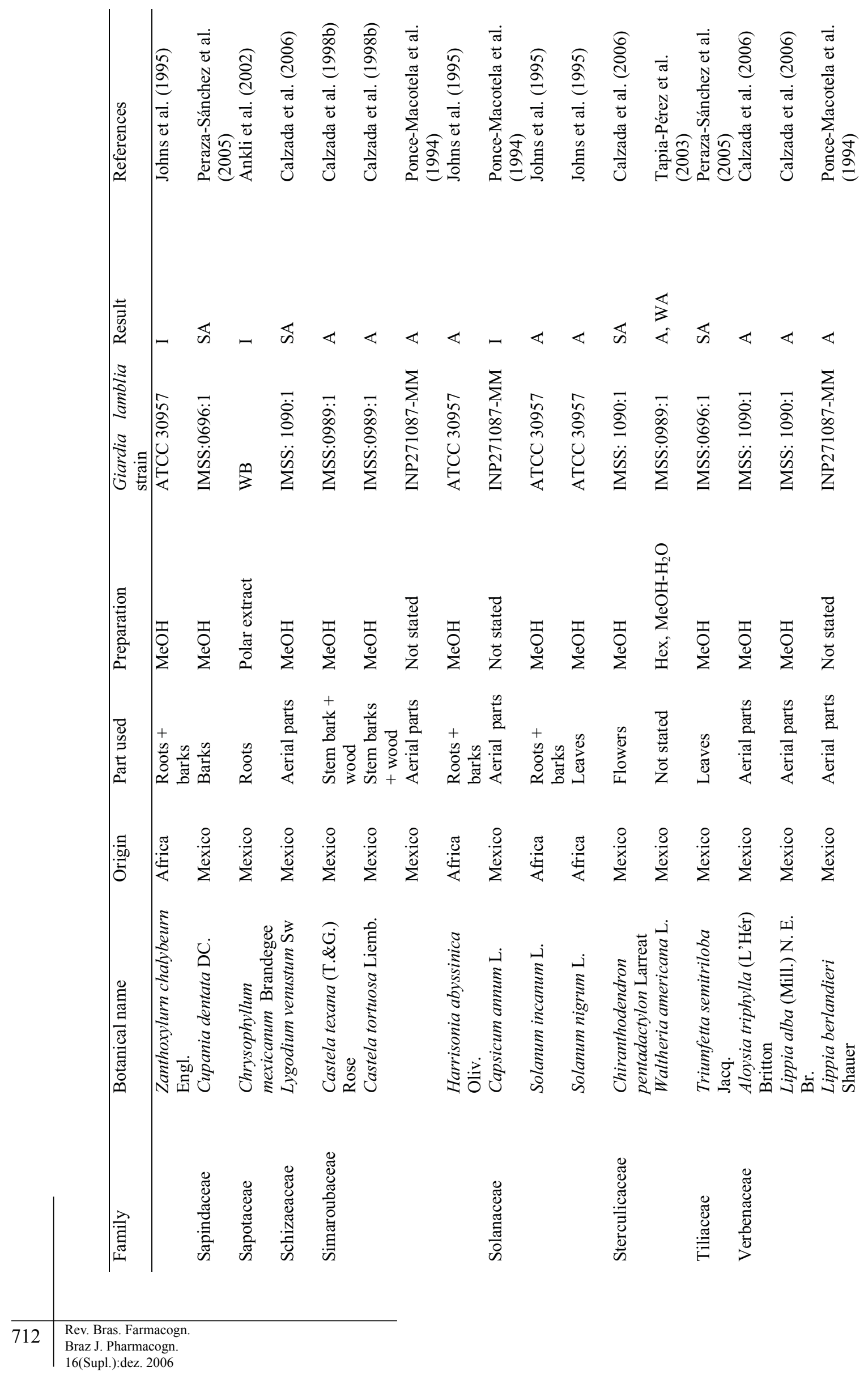




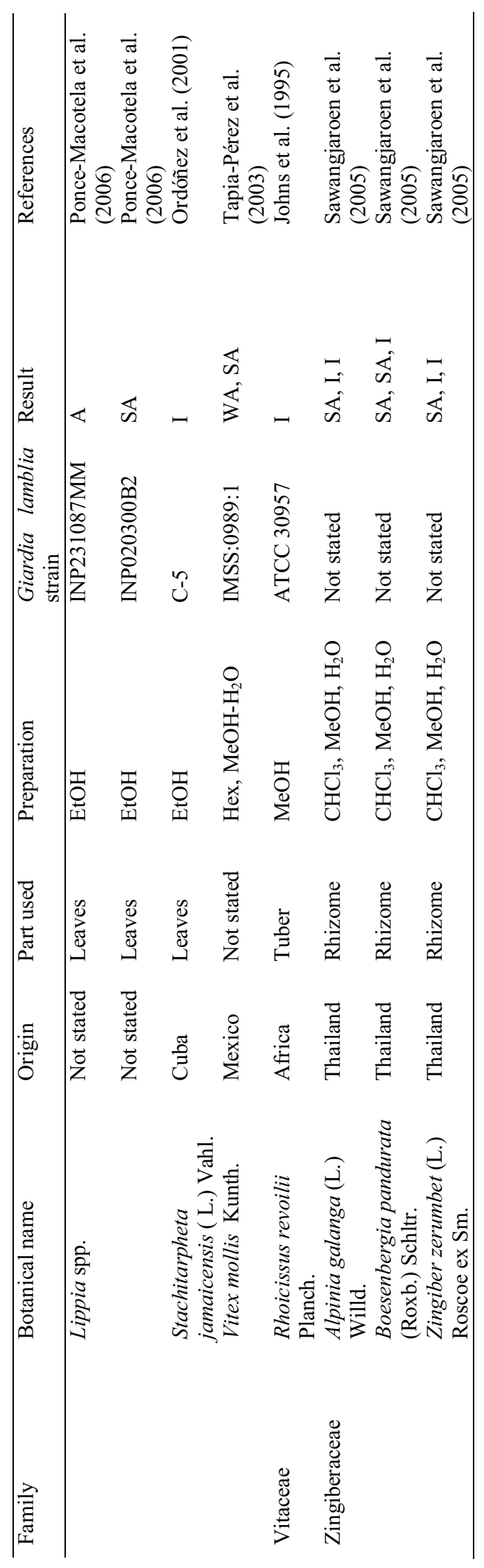

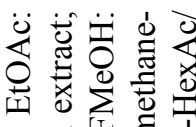

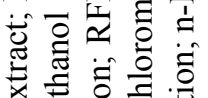

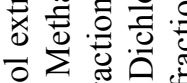

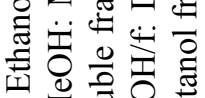

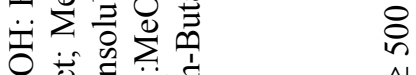

tis

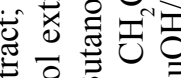

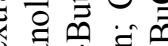

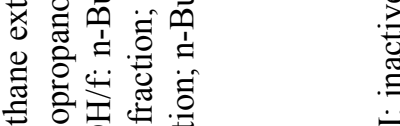

政

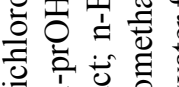

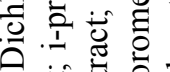

능

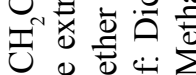

政

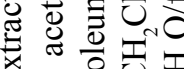

空造语

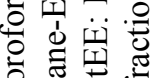

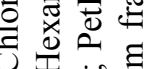

I

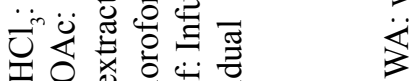

它

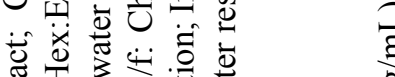

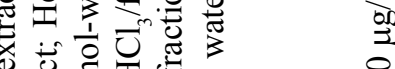

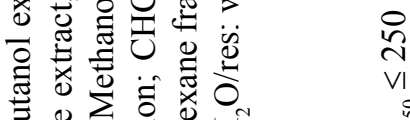

일

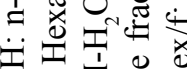

吉范宕离

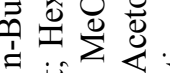

章

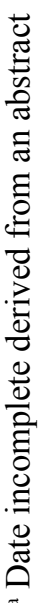

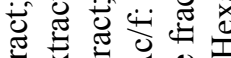

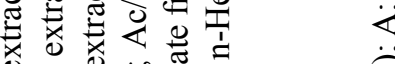

它节

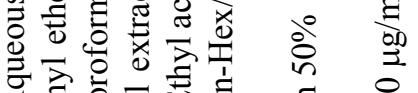

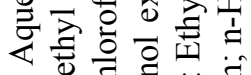

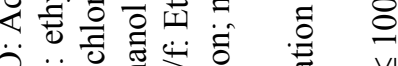

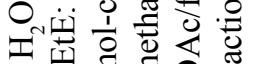

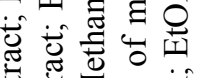

武刻

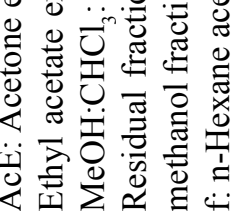

ह 


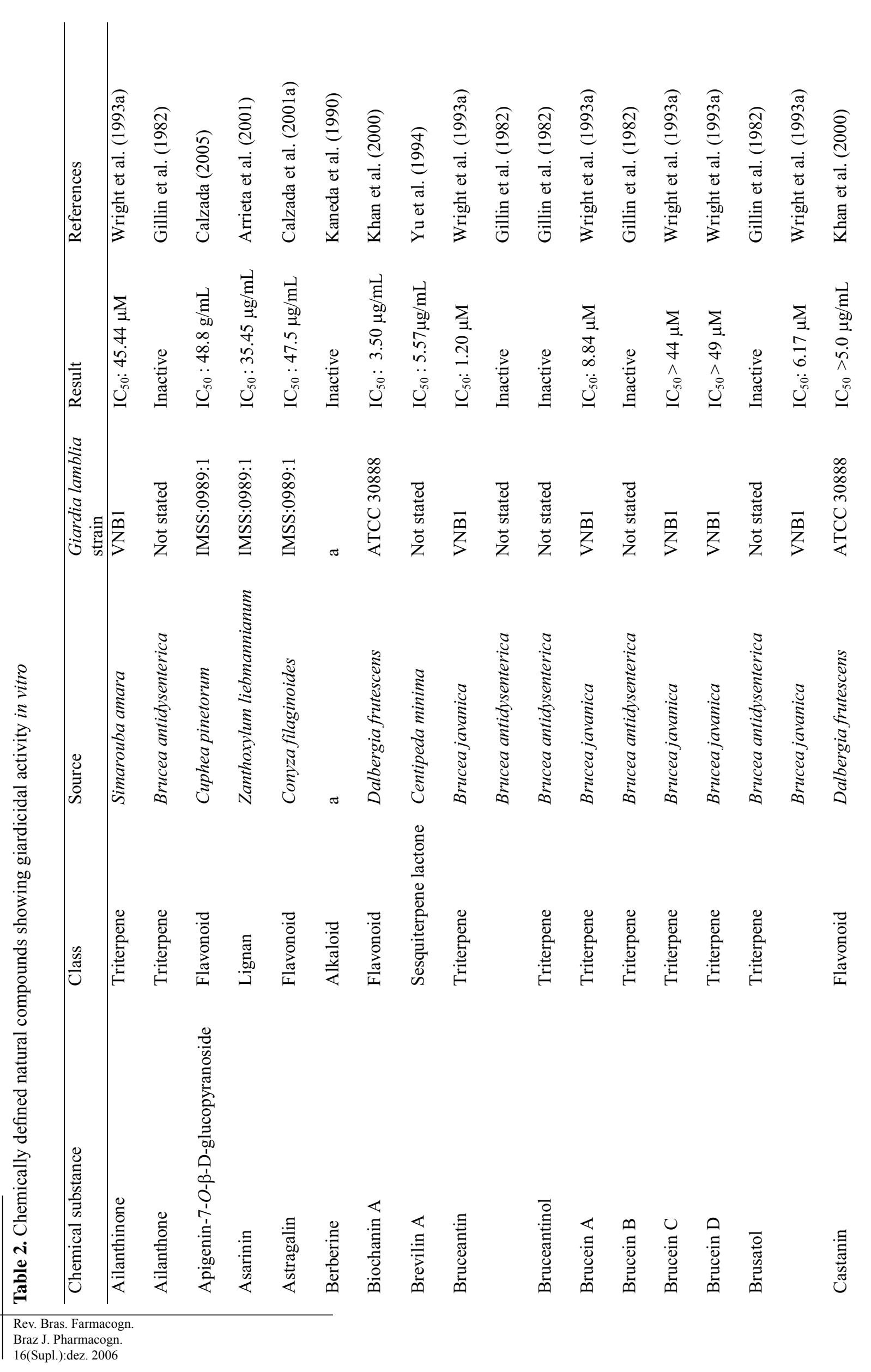




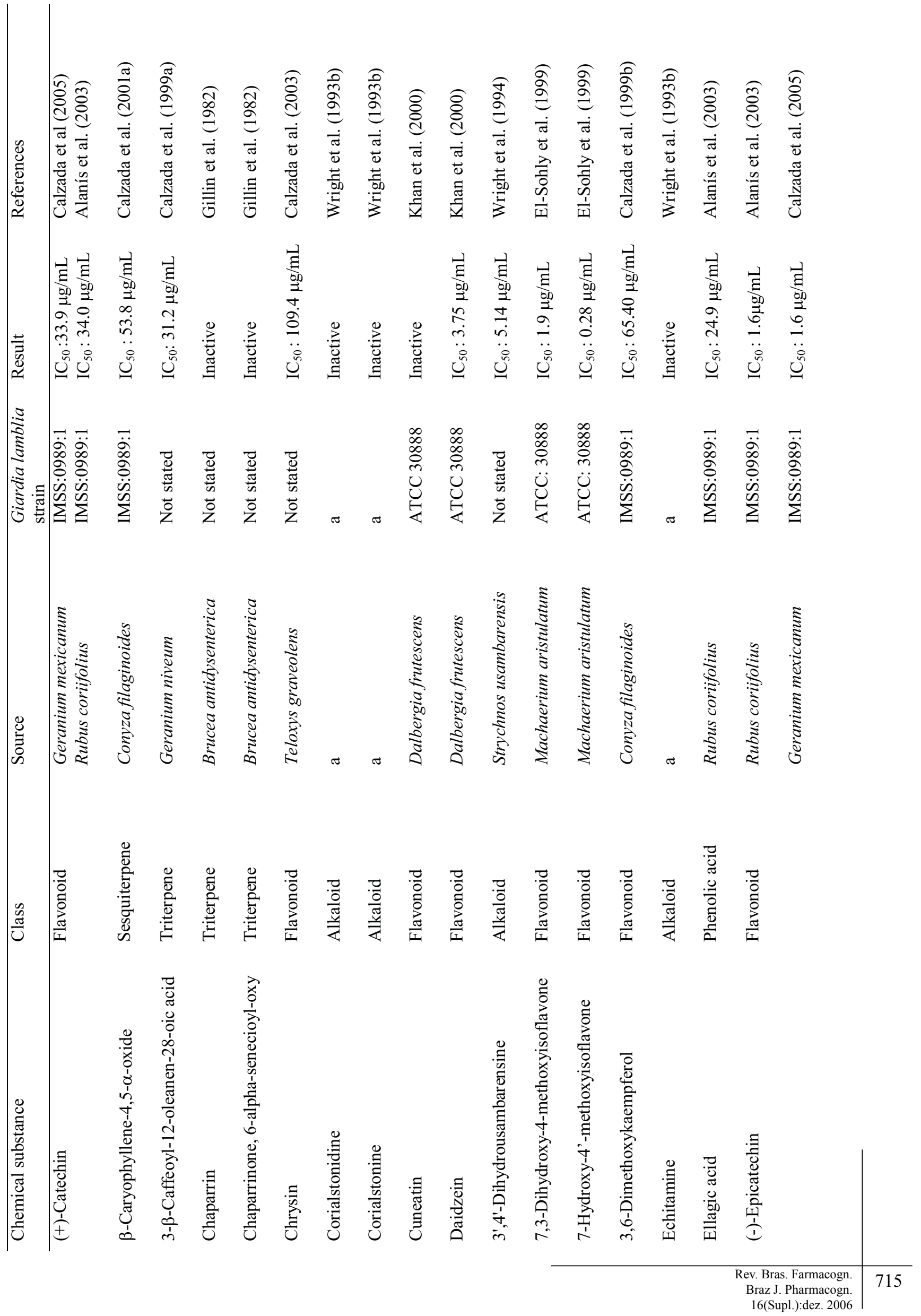




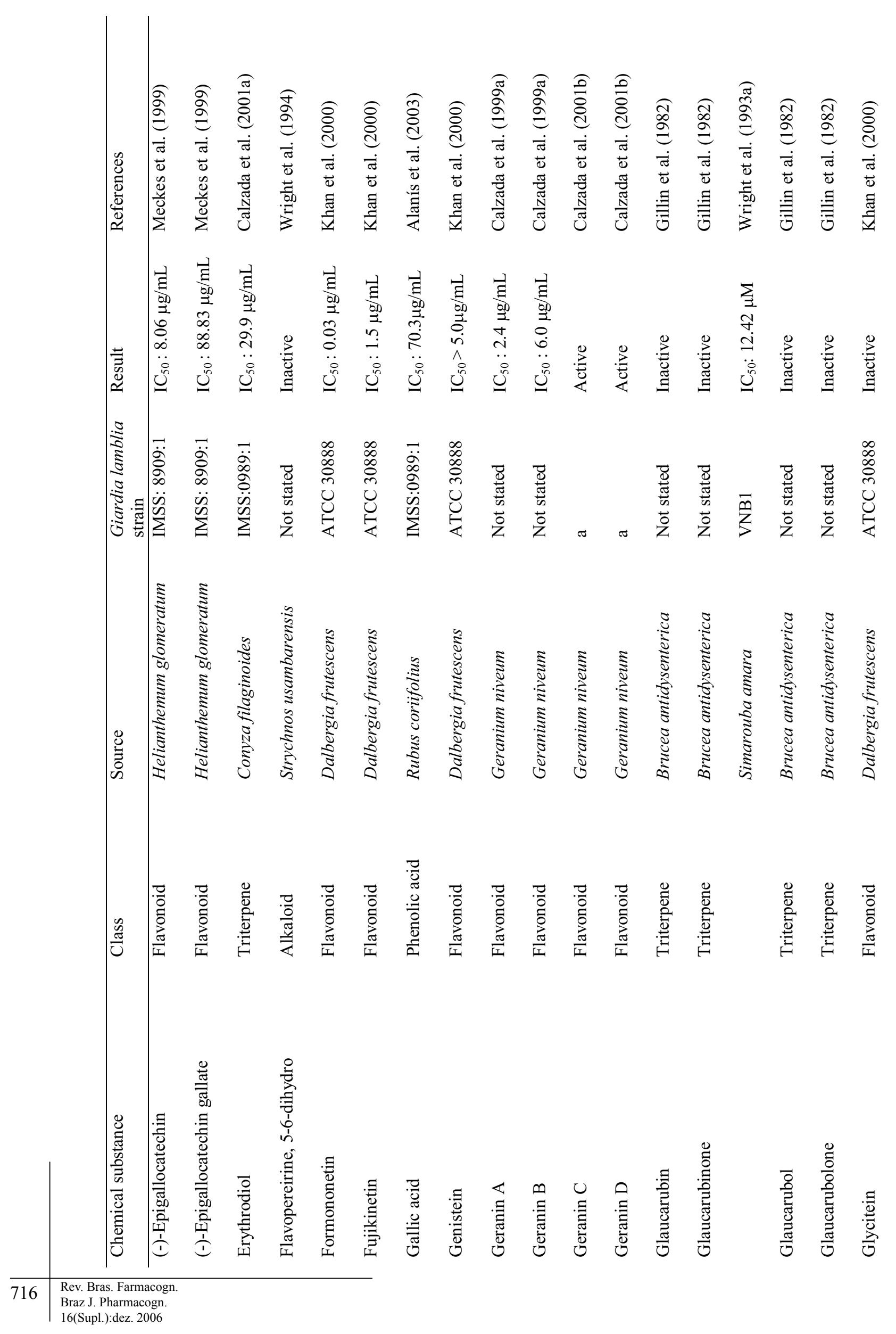




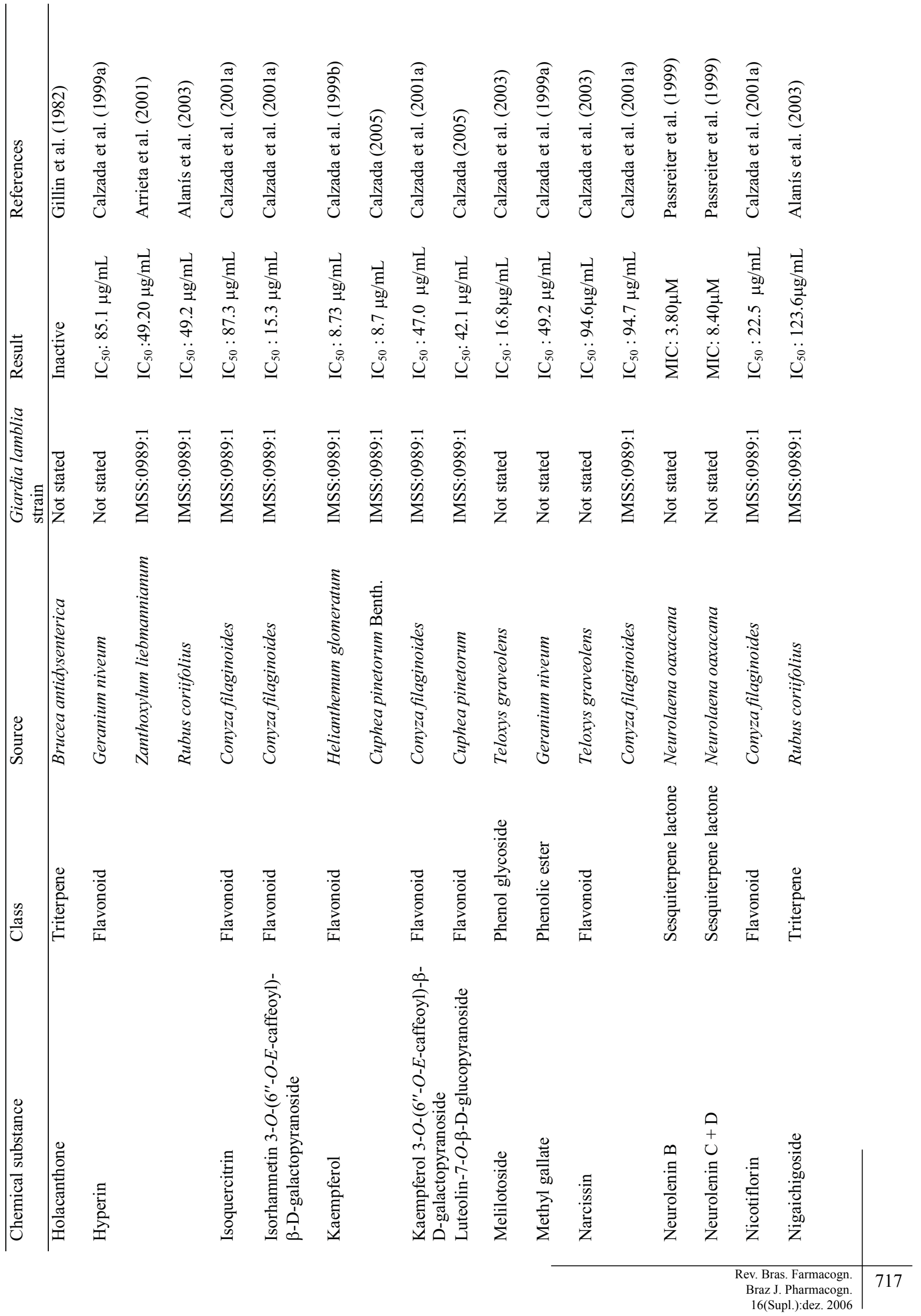




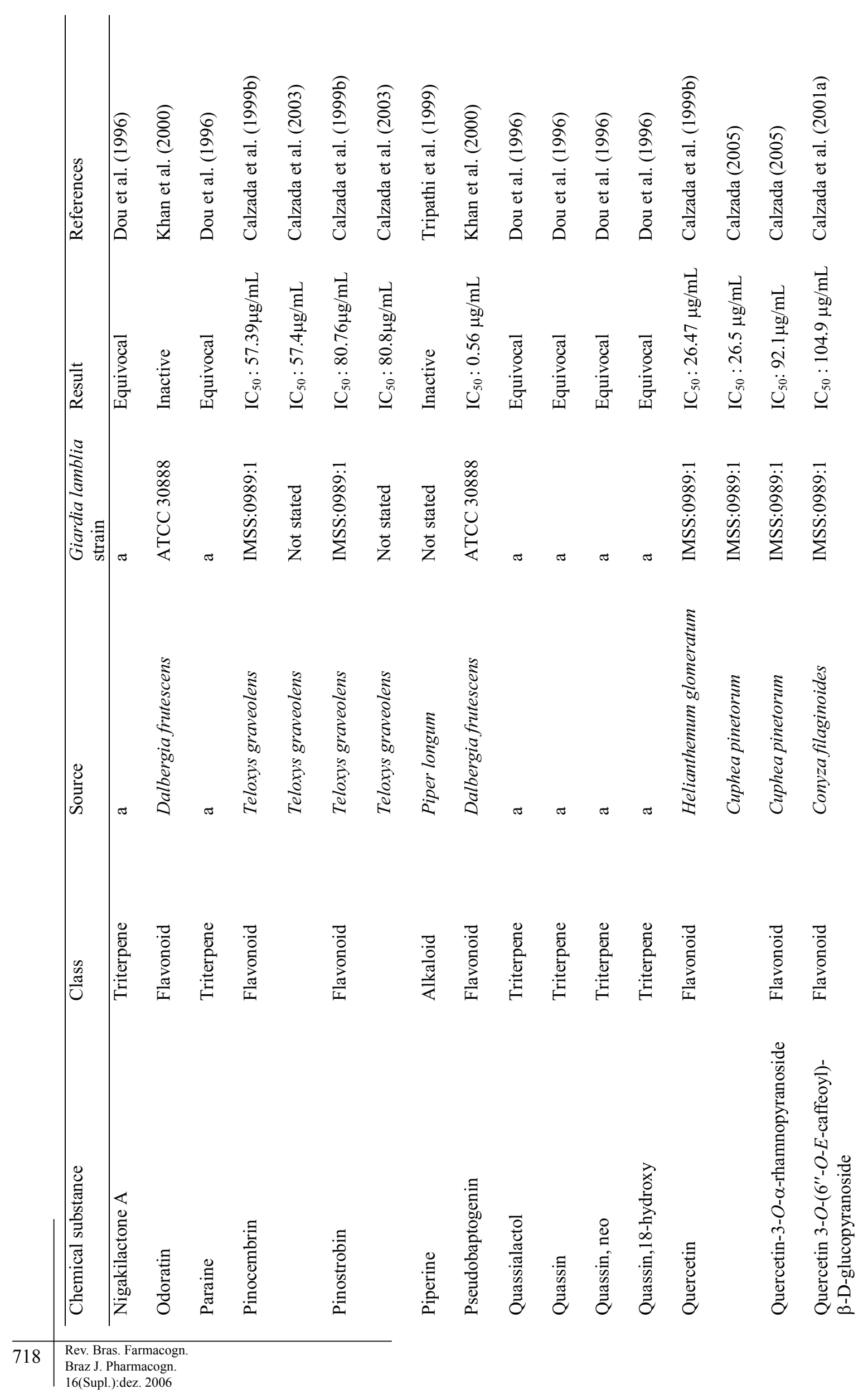




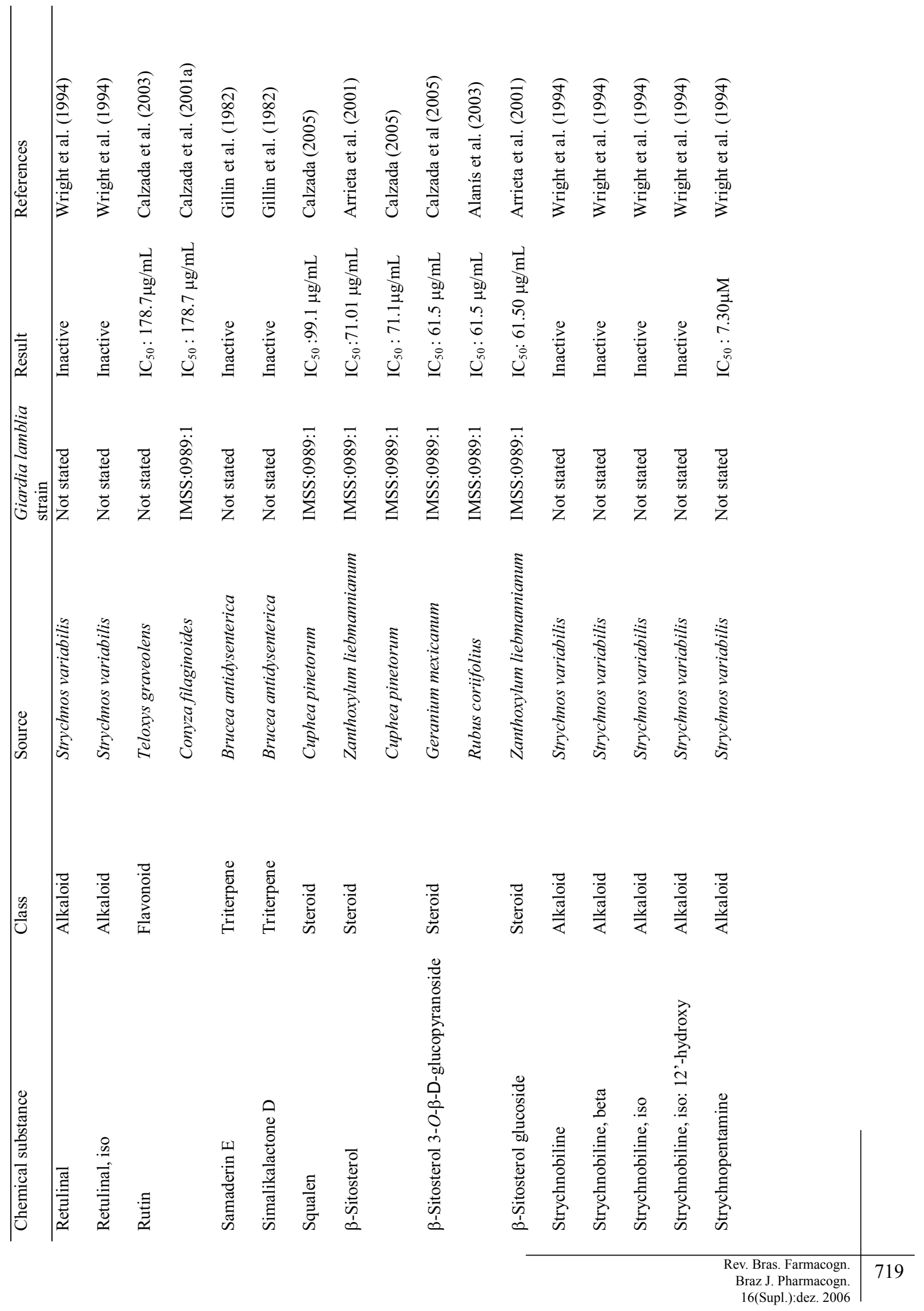




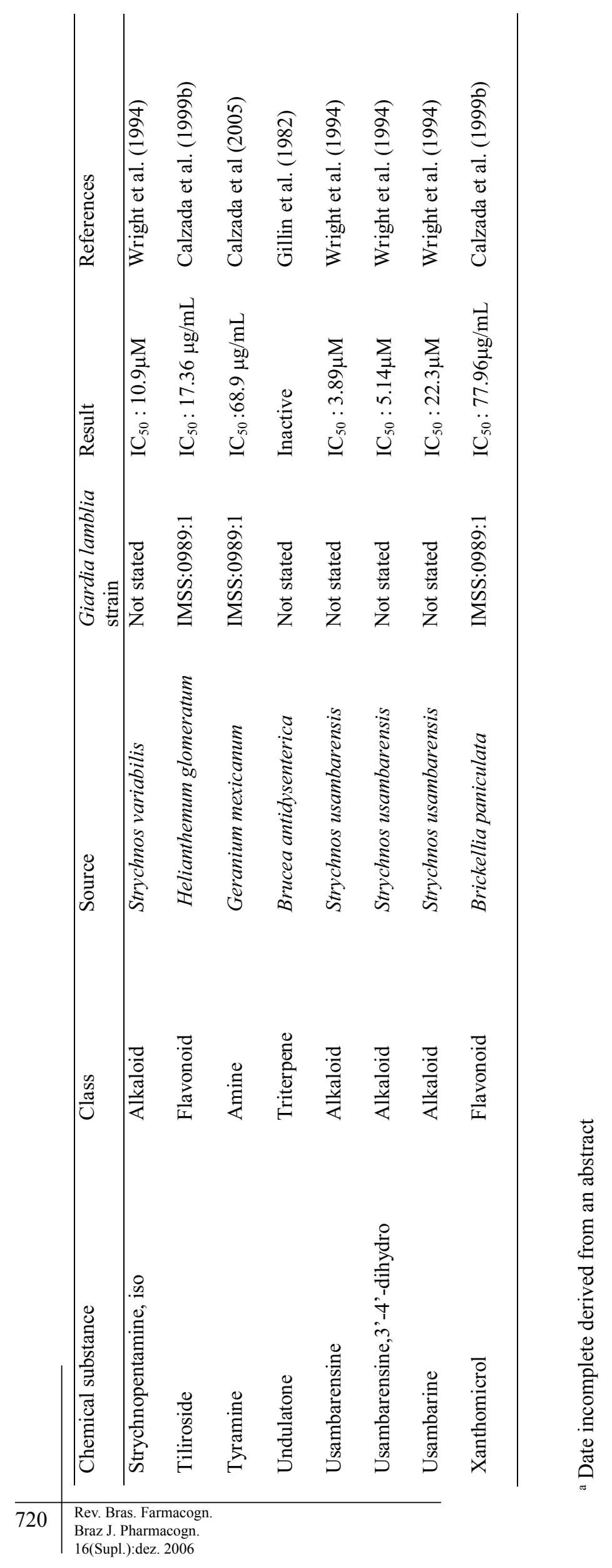

